 \\ Trade credit, the Financial Crisis and Firms Access to Finance \\ Carbo-Valverde, S.; Rodriguez-Fernandez, F.; Udell, G.F. \\ Journal of Money, Credit and Banking
}

DOI:

$10.1111 / \mathrm{jmcb} .12292$

Published: 19/01/2016

Peer reviewed version

Cyswllt i'r cyhoeddiad / Link to publication

Dyfyniad o'r fersiwn a gyhoeddwyd / Citation for published version (APA):

Carbo-Valverde, S., Rodriguez-Fernandez, F., \& Udell, G. F. (2016). Trade credit, the Financial Crisis and Firms Access to Finance. Journal of Money, Credit and Banking, 48(1), 113-143. https://doi.org/10.1111/jmcb.12292

\footnotetext{
Hawliau Cyffredinol / General rights

Copyright and moral rights for the publications made accessible in the public portal are retained by the authors and/or other copyright owners and it is a condition of accessing publications that users recognise and abide by the legal requirements associated with these rights.

- Users may download and print one copy of any publication from the public portal for the purpose of private study or research.

- You may not further distribute the material or use it for any profit-making activity or commercial gain

- You may freely distribute the URL identifying the publication in the public portal ?
}

Take down policy

If you believe that this document breaches copyright please contact us providing details, and we will remove access to the work immediately and investigate your claim. 


\title{
TRADE CREDIT, THE FINANCIAL CRISIS, AND SME ACCESS TO FINANCE
}

\author{
Santiago Carbó-Valverde \\ Bangor Business School and FUNCAS \\ s.carbo-valverde@bangor.ac.uk \\ Phone: +44 1248388852 \\ Francisco Rodríguez-Fernández \\ University of Granada and FUNCAS \\ franrod@ugr.es \\ Phone: +34 958248346 \\ Gregory F. Udell \\ Indiana University \\ gudell@indiana.edu \\ Phone: +1 (812) 855-3394
}

This draft: May 2, 2014

\begin{abstract}
Mounting evidence indicates that firms, particularly SMEs, suffered from a significant credit crunch during this crisis. We analyse for the first time whether trade credit provided an alternative source of external finance to SMEs during the crisis. Using firm-level Spanish data we find that credit constrained SMEs depend on trade credit, but not bank loans, and that the intensity of this dependence increased during the financial crisis. Unconstrained firms, in contrast, are dependent on bank loans but not on trade credit.
\end{abstract}

Keywords: SMEs, financing constraints, bank lending, trade credit, predictability.

JEL classification: G21, D21, L26 


\section{TRADE CREDIT, THE FINANCIAL CRISIS, AND SME ACCESS TO FINANCE}

\section{Introduction}

As the financial crisis began to unfold in the third quarter of 2007 concern mounted that access to finance, particularly for SMEs (small and midsize enterprises) would soon tighten. Exploiting the increasing availability of data since the inception of the crisis, a growing body of academic research has confirmed this conjecture. Much of this research has been focused on determining the existence and magnitude of the credit crunch, identifying which financial institutions contracted the most, how the financial crisis propagated across national boundaries, and which firms were most affected. We focus on a different aspect of the credit crunch: How did firms respond to the contraction of credit supplied by their banks. In particular, we assess whether bank credit constrained SMEs turned to the most important alternative to bank lending as a source of external financing, trade credit.

Trade credit is ubiquitous. Behind bank lending, it is the next most important source of SME external financing in nearly every developed and developing economy (Demirgüç-Kunt and Maksimovic 2001). In the U.S., for example, trade credit provides almost as much debt financing to SMEs as bank loans -- 31.3\% of total debt financing vs. 37.2\% (Berger and Udell 1998). The importance of trade credit has not been lost on the academic community where a relatively larger number of papers have examined how trade creditors underwrite their "loans" and the extent to which they may have an idiosyncratic advantage over banks in extending credit. Moreover, evidence suggests 
that trade credit provides a safety valve for firms facing idiosyncratic liquidity shocks (e.g., Wilner 2000, Boissay and Gropp 2007, Cuñat 2007).

Existing studies have also examined whether trade credit plays a similar role during monetary policy shocks and business downturns. Theoretical work suggests that, at least for some firms whose bank credit becomes constrained, trade credit is countercyclical (Burkart and Ellingsen 2004). On balance, the empirical literature has found that trade credit usage increases in response to monetary tightening (e.g., Calomiris, Himmelberg and Wachtel 1995, Nielsen 2002, Choi and Kim 2005, and Demiroglu, James and Kizilaslan 2012). For the most part, however, these studies are only able to analyze the provision of trade credit (i.e., accounts receivable) and/or the receipt of trade credit (i.e., accounts payable) by large firms, not SMEs, due to data limitations. Although the Nielsen 2002 study which uses the US Census Bureau's QFR data on small firms is an exception, these data are not disaggregated.

A few studies have looked at trade credit prior to financial crises (Love, Preve and Sarria-Allende 2007, and Taketa and Udell 2007). But these studies also lack firm-level data on SMEs. In the only analysis of trade credit during the current financial crisis of which we are aware, the evidence suggests that in the U.S. stronger larger firms extended more trade credit and weaker larger firms received more trade credit -- Garcia-Appendini and Montoriol-Garriga (2013) hereafter referred to as G-M. Our analysis differs in several important ways from G-M. Most importantly our analysis focuses fundamentally on how trade credit affects investment (i.e., capital expenditures) by credit constrained firms rather than how credit flowed from liquid to constrained firms. In this sense our paper is nested squarely in the literature on the real effects of the crisis on the economy 
(e.g., Duchin et al. 2010, Almeida et al. 2012). These real effects stem from the fact that trade credit can provide access to capital for firms that are unable to fund through more "traditional" channels (Petersen and Rajan 1997). That is, by allowing firms to postpone payment for raw materials, suppliers concomitantly allow firms to avoid tapping other sources of finance. For most SMEs the only other viable external source is bank debt. By its nature trade credit is revolving in the sense that as long as the firm pays its supplier within the prescribed invoice maturity, the firm is typically allowed to continue purchasing new material (under new invoices with the same maturity as the paid invoices).

Recent studies have found evidence of considerable variance in the maturity of trade credit across firms. Giannetti et al. (2007) found that in a representative sample of small firms the standard deviation of the maturity of trade credit was over 12 days around a mean maturity of about 25 days. Our focus differs from Giannetti et al. (2007) in that we investigate the potential effect of an increase in the maturity of trade credit during a credit crunch - an increase that could be used to offset a decrease in the supply of banks loans - and, given that funding is fungible, whether this increase in trade credit is used to finance capital expenditures that would have otherwise been financed with these bank loans. $^{1,2}$

\footnotetext{
${ }^{1}$ For example, using the summary statistics from Giannetti et al. (2007) as an illustration, increasing the maturity of trade credit during a credit crunch by a one standard deviation from the mean would generate funding equal to almost $50 \%$ of existing trade credit. That is, for a firm with $\$ 1$ million of accounts payable this would generate $\$ 500,000$ of financing that could replace a $\$ 500,000$ contraction of trade credit. This funding would come from 12 days of cash flow that would have otherwise been used to pay invoices due in 25 days (that are now due in 37 days).

${ }^{2}$ Although Duchin et al. (2010) and Almeida et al. (2012) do not analyze trade credit, they both investigate financing alternatives in the context of the financial crisis. These two papers find that for large firms in the U.S. the impact of the crisis on investment was related to debt maturity (i.e., the more short term debt or the more that long debt is currently maturing, the less investment). Our analysis focuses on much smaller firms who typically do not have access to general purpose long term debt (e.g., Carey et al. 1992, Berger and Udell 1998) and for whom trade credit is the only major alternative source of debt (Berger and Udell 1998).
} 
In addition, our paper focuses on the most vulnerable segment of the market, SMEs. This SME focus is missing in G-M's study on this current crisis - and is missing in all other studies of trade credit during prior macro shocks. As a result until our study we can only speculate on whether an increase in the supply of trade credit cushions the contraction of bank credit to credit constrained SMEs after macro-shocks. That is G-M and other prior studies on trade credit only tell us that certain types of large firms extend more trade credit during macro shocks - but whether this increase in trade credit went to SMEs and, more importantly, whether it went to credit constrained SMEs.

We address this important gap in the literature by exploiting a large database that includes panel financial statement and banking relationship data on nearly 40,000 firms in Spain over the period 1994-2010. In many countries, including the U.S., firm-level data sets during the financial crisis such as ours simply do not exist. In addition, we employ for the first time in the trade credit literature a disequilibrium model methodology that extracts from financial statement data estimates of credit demand and supply in order to identify credit constrained (i.e., vulnerable) SMEs. We then use this result to examine how funding differs between two types of SMEs, unconstrained firms and constrained firms; and how this difference changes from pre- to post-crisis.

We find that unconstrained firms depend more on bank financing to fund capital expenditure while constrained firms depend more on trade credit. More precisely, for unconstrained firms, bank funding predicts capital expenditure (but not trade credit) and for constrained firms, trade credit predicts capital expenditure (but not bank loans). We also find that the magnitude of these effects increases during the credit crunch. Taken

In effect, we test whether trade credit can act in a crisis as a source of financing for long-term investment. That is, we test whether the strong relationships between clients and suppliers that allow trade credit to be rolled over enable trade credit to provide funding for long-term investments. 
together our analysis indicates three things: i) financially constrained firms are more dependent on trade credit to make their investment decisions; ii) the financial crisis was associated with a credit crunch that affected the SME sector by increasing the number of credit constrained firms; and, iii) capital expenditure sensitivity to trade credit increased during the crisis period.

Spain is a particularly interesting venue for studying this phenomenon for several reasons. Beyond just its data advantages, Spain now plays a critical role in the health of the European Monetary Union. Unlike some of the other hardest hit EMU economies such as Cyprus, Greece, Ireland and Portugal, Spain is large enough to affect the ultimate fate of the Euro. Moreover, a major component of its banking system, the cajas savings banks, imploded creating one of the most serious credit crunch conditions in this crisis (see Illueca, Norden and Udell 2014).

Our paper proceeds as follows. In the next section we briefly discuss the streams of literature that relate to our analysis: the literature on trade credit, the literature on the financial crisis and SME finance, and the intersection of these two literatures. In Section III we describe our data and our methodology. In Section IV we present our results. Section V concludes.

\section{Related Research}

\section{II.A. The Potential Advantages of Trade Credit}

A considerable body of research has been devoted in recent decades to analysing the role of trade credit in providing firms with external finance. There is some evidence to indicate that trade creditors might even have an advantage over other lenders 
(specifically, banks) in providing credit to especially opaque firms. Among these arguments is the possibility that suppliers may act as "relationship lenders" because they have unique proprietary information about their customers (McMillan and Woodruff, 1999; Uchida et al., 2013). Some papers find that suppliers can obtain information about customer quality that is unavailable to banks (Smith 1987, Biais and Gollier 1997). One paper shows that trade suppliers may have an advantage in enforcing unsecured debt contracts (Cuñat 2007). This advantage allows suppliers to extend more credit than banks when their customers are rationed in the bank loan market. Another paper has shown that smaller suppliers extend more trade credit to larger creditworthy borrowers as a mechanism to signal product quality (Klapper, Laeven and Rajan 2011).

Demirguç-Kunt and Maksimovic (2001) also emphasize that information about a firm's customers is potentially valuable and that sellers act on this information to extend credit on terms that are not available from banks. Some have suggested that this supplier information advantage in funding opaque firms may imply a complementarity between trade credit and bank loans (Cook, 1999; Ono, 2001; García-Appendini, 2006). However, this argument is not necessarily inconsistent with the view that bank loans are a less expensive substitute for trade credit (e.g., Meltzer, 1960; Brechling and Lipsey, 1963; Ramey, 1992; Marotta, 1996; Uesugi and Yamashiro 2004; Tsuruta, 2008). It has been suggested that both views (substitutes and complements) can be reconciled by conditioning on whether firms are financially constrained or not (García Appendini, 2006). ${ }^{3}$

\footnotetext{
${ }^{3}$ See Giannetti et al. (2011) and Uchida and Udell (2012) for comprehensive reviews of this now extensive literature.
} 


\section{II.B. The Literature on SME Credit Access During the Current Financial Crisis}

The literature on the impact of the current crisis on access to credit is now growing at a rapid rate as the passage of time makes more data available to the research community. Some of the earliest studies focused on the U.S. and found evidence of significant supply shocks to the terms and availability of credit to larger firms (e.g., de Haas and van Horen 2010, Ivashina and Scharfstein 2010, Almeida et al. 2012). As we noted above, however, the U.S. has not been a good venue to study the impact of the crisis on credit access by SMEs. Consequently, much of the research on how more informationally opaque firms were affected by the contraction of credit has been focused elsewhere, particularly Europe where SME data is more available.

A key challenge in this literature is sorting out demand and supply effects. ${ }^{4}$ Papers that have looked at credit crunch effects at the firm level have taken several different approaches. One approach has been to use loan application data to control for demand (e.g., Puri et al. 2011, Popov and Udell 2012, Ongena et al. 2013, Presbitero et al. 2014). Another approach has been to use firm fixed effects in countries where multiple banking relationships are common in the SME sector (e.g., Albertazzi and Marchetti 2010, Iyer et al. 2010, Jimenez, et al. 2012). Overall the literature suggests that the credit crunch in the SME sector was economically significant, that weaker banks (measured in a variety of different ways) contracted their credit more, and some -- but not all found -that weaker and more opaque firms were more adversely affected. ${ }^{5}$

\footnotetext{
${ }^{4}$ Occasionally natural experiments occur where supply shocks are necessarily insulated from demand shocks as in the case of Japanese subsidiaries in California during the Japanese financial crisis (i.e., Peek and Rosengren 1997). This, however, does not apply in this crisis.

${ }^{5}$ See Presbitero, Udell and Zazzaro (2013) and Popov and Udell (2012) for recent summaries of the literature on SME access to finance and the current financial crisis.
} 


\section{II.C. The Intersection of the Crisis, Real Effects and Trade Credit}

In order to fully assess the impact of the credit crunch on the SME sector all sources of external finance must be considered. One type of lending might substitute for another type of lending; and, one type of lender might substitute for another type of lender (Taketa and Udell 2007, Udell 2009). In this paper we study the most important alternative to bank lending in the SME sector, trade credit.

As we noted above some papers have analyzed whether trade credit and bank loans are substitutes or complements. We ask a more specific question in this paper: Did SMEs crunched out of the bank loan market turn to trade credit as an alternative source of finance for their capital expenditures during the crisis? There are three papers on trade credit and financial crisis that are related to our analysis. One of these papers - the first chronologically - found that larger firms in the U.S. used their access to the commercial paper market to fund an increased extension of trade credit during monetary policy shocks (Calomiris, Himmelberg and Wachtel 1995). The second paper looked at the Japanese financial crisis of the 1990s (the "lost decade") - a crisis that in many ways mirrored the current U.S. financial crisis. This paper found little evidence that trade credit played much of a role as a lender of last resort in Japan (Taketa and Udell 2007). The lack of firm level data in this study, however, limited its ability to draw distinctions among firms with respect to their use of trade credit.

The third study, G-M, is the closest to ours because it used firm-level U.S. data to look at trade credit flows during this crisis. G-M found evidence that firms with large levels of pre-crisis liquidity extended more trade credit during the crisis. It also found that financially constrained firms utilized (received) more trade credit. This study, 
however, was limited to large firms with a market capitalization of \$50 million or more or a book value of $\$ 10$ million or more. (As we noted above, data limitations in the U.S. like Japan during the "lost decade” - preclude firm-level analyses of SMEs.) ${ }^{6}$ At first blush, it might seem reasonable to speculate that this finding on trade credit for large firms would also apply to SMEs based on the argument that if an effect is found for inherently more transparent (i.e., large) firms with access to the capital markets, it likely applies to firms that are less transparent (SMEs). But, some caution must be exercised in extrapolating this result on large U.S. firms to U.S. SMEs for several reasons. First, the magnitude of the effect might be quite different between large and small firms. Second, the financial crisis in the U.S. hit large banks first. Small banks who lend exclusively to SMEs were hit later and hit by different factors, most importantly commercial real estate. Finally, the G-M study can't tell us whether larger "liquidity unconstrained firms" were as willing to extend increased trade credit to smaller SMEs as they were to other large firms (who were likely bigger customers).

Thus, our paper is quite distinct from G-M (i.e., the only other paper to study trade credit during the financial crisis) in that we specifically analyze SMEs, not large firms. Moreover, our focus is quite different: instead of emphasizing how trade credit flows from liquid firms to constrained firms, we focus on the sensitivity of investment to trade credit and bank credit. That is, while in G-M the dependent variables are accounts receivable/payable, our main dependent variable is capital expenditures. This connects our paper to an important recent stream of literature that examines the real effects of the crisis on the economy. This literature includes, in particular, papers that have examined

\footnotetext{
${ }^{6}$ This study used Compustat data and the authors also effectively eliminated mid-sized firms with their size filter because of concerns about the quality of the accounting data for these firms.
} 
how corporate liquidity affected corporate investment during the crisis (e.g., Campello et al. 2010 and Duchin et al. 2010) and more generally the interaction among financial distress, corporate liquidity and asset allocation (Almeida et al. 2012). We add a new dimension to this research on the real effects of the crisis by focusing on SMEs, arguably the most vulnerable sector of the economy and the sector for which there is a virtual absence of data in the U.S.

We also differ significantly from G-M in terms of methodology. In particular, we employ a very different approach to the proxies used in the G-M study to measure whether firms are financially constrained. The three proxies used in G-M are the KaplanZingales (1997) index, the Whited-Wu (2006) index, and the dividend payout measure. These measures are calibrated for large firms that pay dividends and have access to the capital markets (i.e., large firms that have access to debt sources beyond bank loans including the private placement market, the commercial paper market, the medium-term note market and the corporate bond market. These indexes are not appropriate for the SME market. In Spain, like many other countries, the only two meaningful sources of external finance for SMEs are bank loans and trade credit. ${ }^{7}$ So, we specifically model firms that are bank constrained, the relevant benchmark in an SME context. Also, our focus on the SME sector is particularly relevant in a European context where most firms and most employment reside in this sector. ${ }^{8,9}$

\footnotetext{
${ }^{7}$ In the U.S. commercial finance companies also provide a significant of SME finance (e.g., Berger and Udell 1998).

${ }^{8}$ This is not to say that the SME sector is unimportant in the U.S. where the SME sector is probably at least $40-45 \%$ of GDP depending on how one defines an SME.

${ }^{9}$ There are two recent papers that have studied investment sensitivity in a Kaplan-Zingales framework during this financial crisis. However, neither of these papers examine trade credit or demand factors potentially affecting access to funding by firms. The first paper, Duchin et al. (2010), analyzes a sample of U.S. firms during 2003 to 2009 and find that the negative supply shocks on firm investment during the crisis are larger for firms that have low cash reserves or high net short-term debt, ,or operate in industries
} 


\section{Data and Methodology}

\section{III.A. Empirical Strategy and Data}

Our empirical strategy involves two main steps. First, we identify firms that are financially constrained. This has been a significant challenge in analyzing SME access to finance and the impact of macro shocks including the current credit crunch. The chief problem is disentangling supply effects from demand effects. Occasionally natural experiments present themselves that, in a sense, opportunistically solve the problem. For example, Peek and Rosengren (1997) investigated how the collapse of the real estate market in Japan affected the provision of credit by Japanese bank subsidiaries abroad. Unfortunately these types of natural experiments are rare. Another approach is to exploit firm-level survey data to separate demand and supply where respondents report whether they applied for credit, whether they were discouraged from applying for credit, and whether they received the credit they asked for (e.g., Popov and Udell 2012, Presbitero et al. 2014). This approach has the virtue of a strong identification strategy but these surveys generally have only limited information on the financial characteristics of the borrower. Another approach involves using loan application data from credit registries that have both firm-level financial statement information and application information

dependent on external finance. In the second of these papers dealing with firm investment during the crisis, Almeida et al. (2012) analyze the relationship between firm investment and debt maturity at U.S. companies. They find that firms whose long-term debt was largely maturing right after the third quarter of 2007 cut their investment-to-capital ratio more than otherwise similar firms whose debt was scheduled to mature after 2008. 
(e.g., Jimenez et al. 2012). However, these data do not fully account for demand effects because they lack information on discouraged borrowers. ${ }^{10}$

We adopt a different identification approach that avoids the data limitations that stem from a lack of information on firm financial conditions inherent in current survey data and the data limitations on demand effects inherent in credit registries that only observe actual applications. Our approach involves estimating credit demand and supply from panel data on firm financial statements. Specifically, we estimate the probability that a firm will experience borrowing constraints using a disequilibrium model (Maddala 1980) that allows us to identify the set of (information-based and other) supply and demand factors that may affect the wedge between the costs of internal and external funding. This permits us to classify firms as constrained or unconstrained using both cross-section and times series information.

In the second step, in order to assess the relative dependence on bank loans versus trade credit, we conduct an analysis of the effect of these two sources of external funding on investment using Granger predictability tests. That is, we test whether i) investment for unconstrained firms is sensitive to (i.e., caused by) bank loans; and ii) investment for constrained firms is sensitive to (i.e., caused by) trade credit. In some sense this can be viewed as looking at the "dual” of the cash flow-investment sensitivity approach where the sources of investment funding are either banks loans or trade credit.

Our data come from four sources. Two of the sources contain data for the SMEs that we analyse. The first of these is the Bureau-Van-Dijk Amadeus database which

\footnotetext{
${ }^{10}$ In a similar fashion Puri et al. (2011) investigated consumer and mortgage lending by savings banks in Germany using data from the savings bank association and banks' loan-level ratings. But, likewise, these data don’t captured discouraged-borrower effect.
} 
contains firm characteristics including financial information ${ }^{11}$. The second source of data is the SABI (Sistema de Análisis de Balances Ibéricos), another database by Bureau Van Dijk which overlaps with Amadeus but in addition contains the name of the bank(s) with whom the firm has a relationship, including, importantly for our purposes, lending relationships ${ }^{12}$. The third data source is the public financial information on Spanish banks provided by the two main banking associations (Spanish Commercial Bank Association, AEB, and Spanish Savings Banks Confederation, CECA). Finally, the fourth data source is the macroeconomic information provided by the INE (the Spanish Statistics Office).

Our dataset allows us to combine SME information with regional-level macroeconomic, bank market industry variables (i.e., local market power) and relationship lending characteristics. This is critical in using our disequilibrium model to classify firms as either constrained our unconstrained.

Our final sample covers 38,329 firms over the period 1994-2010, which represents around $5 \%$ of total firms in Spain on average over the sample period. Due to entry and exit of the firms, the panel is unbalanced and the number of firm-year observations is $528,317^{13}$ Our sample period spans a pre-crisis period from 1994-2006 and a crisis period from 2007-2010. Definitions of our variables and simple correlations are provided in the appendix. Descriptive statistics are shown in Table I including our main variable of interest, "capital expenditure/capital". While its mean over the sample period is .33, it varies in interesting ways related to the crisis. Figure 1 shows that it

\footnotetext{
${ }^{11}$ We follow the European Commission and define SMEs as those firms with less than 250 employees.

${ }^{12}$ The information on bank-firm relationships is updated every year in the SABI dataset.

${ }^{13}$.For the small number of medium-sized enterprises that are owned by a holding company, we use the consolidated financial statements.
} 
increases from about .3 in 2001 to about .4 in 2007 and then significantly declines over the crisis years to about zero in 2009 and 2010.

\section{III.B. Identification of Financially Constrained Firms}

The disequilibrium model that we employ to identify whether firms are financially constrained consists of two-reduced form equations: a demand equation for bank loans, and a supply equation that reflects the maximum amount of loans that banks are willing to lend. A third transactions equation restricts the value of loans as a min equation of desired demand and loan supply. From an econometric point of view, the main challenge associated with estimating the model is that one has to obtain estimators for the parameters of the loan supply and demand functions using only the observed volume of transactions in the loan market. We use the max likelihood method in Maddala and Nelson (1974) and Maddala (1980) to estimate the model. These models have been used before to analyze credit markets in different countries (see e.g. Sealey 1979; Perez 1998, Ogawa and Suzuki 2000; Atanasova and Wilson 2004; Steijvers 2008 or Carbó et al. 2009). ${ }^{14}$

Our loan demand ( Bank loans ${ }_{i t}^{d}$ ), loan supply ( Bank loans $s_{i t}^{s}$ ), and transactions equations (Bank loans $_{\text {) }}$ ) for firm $i$ in period $t$ are:

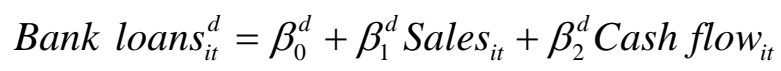

$+\beta_{3}^{d}$ Loan interest spread $_{i t}+\beta_{4}^{d}$ GDP growth $+u_{i t}^{d}$

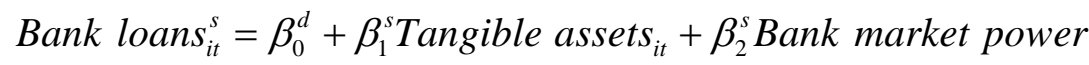

$+\beta_{3}^{s}$ Default risk $k_{i t}+\beta_{4}^{s} G D P$ growth $+u_{i t}^{s}$

\footnotetext{
${ }^{14}$ We are assuming here that trade credit is more expensive than bank loans. Thus, we can focus on bank loans to determine whether firms are constrained in their access to external finance.
} 
Bank loans $_{i t}=$ Min $\left(\right.$ Bank loans $\left._{i t}^{d},{\text { Bank } \text { loans }_{i t}^{s}}^{\mathrm{a}}\right)$

The identification problem is solved in the disequilibrium model by attributing the observed changes in the quantity of loans to underlying movements in the loan demand and loan supply functions.

Our bank loan demand equation (1) is modelled as a function of firm activity (Sales), internal financing (Cash flow), and the firm's interest spread on its bank loans (Loan interest spread). The latter is computed as the difference between the loan interest rate and the interbank interest rate ${ }^{15}$. The Sales variable is included to capture demand for bank loans to finance firm assets including accounts receivables, inventory and fixed assets. Cash flow controls for internal funds that may be used in lieu of external bank financing. The interest rate spread captures the cost of such financing. The maximum amount of credit available to a firm (i.e., the supply of credit) is modelled as a function of the firm's collateralizable assets (Tangible assets), the banks' local market power measured by the Lerner index (Banks' market power), ${ }^{16}$ and a proxy for firm default risk (Default risk) which is defined as the ratio of operating profits over interest paid.

Tangible assets controls for the likelihood that, other things equal, banks will be willing to lend more to firms with more collateral. The Banks' market power indicator captures the extent to which bank competition may alter the supply curve. Default risk measures the extent to which a firm's risk profile may affect the supply of bank loans (with a coverage ratio commonly used by bankers to assess credit quality).

\footnotetext{
${ }^{15}$ In the absence of specific data on a firm's loan interest rate we proxy this rate with the ratio of interest expense to bank loans outstanding. We implicitly assume that the year-end loan balance is roughly equal to the weighted average balance during the year.

${ }^{16}$ See Cetorelli and Gambera (2001). The Lerner index is defined as the ratio "(price of total assets marginal costs of total assets)/(price of total assets)". The price of total assets is directly computed from bank-level auxiliary data as the average ratio of "bank revenue/total assets" for the banks operating in a given region using the distribution of branches of banks in the different regions as the weighting factor. Marginal costs are also estimated from the auxiliary sample.
} 
All non-ratio variables are converted into ratios (of total assets) to reduce heteroscedasticity. As a consequence, the size (scale) effect of "total assets" in the demand function above is estimated as part of the constant term since the constant term is estimated as a coefficient of the reciprocal of total assets. Both the demand and supply equations contain GDP growth to control for macroeconomic conditions across the regional markets where the SMEs operate. Equations (1) - (3) represent our baseline model.

We also consider alternative specifications. It could be argued, for example, that Sales and Cash flow could also enter the demand equation. Cash flow could affect loan supply through its importance in covenants such as those on coverage ratios (Sufi 2009). Similarly, it could be argued that Tangible Assets might also enter the demand equation because these assets need to be financed and Default Risk might also enter the demand equation as this may proxy the growth opportunities.

The strength of the bank-borrower relationship might also be a determinant of loan supply for banks (Petersen and Rajan, 1994 Berger and Udell 1995). The SABI database allows us to proxy relationship strength in the supply equation with three different variables: the age of the firm, the length of the relationship measured as the length in years of the relationship between the firm and its main bank (we assume the main bank is either the only bank working with the firm or the bank with the longest relationship), and a dummy variable showing whether the firm has a single (0) or multiple (1) bank relationships.

Our first alternative model, following the discussion above adds Tangible assets and Default risk to the demand equation and Sales and Cash-flow to the supply equation. 
A third model adds the relationship lending variables (Age of the firm, Number of years of the relationship, and Single vs. multiple bank relationships) to the supply equation.

Finally, a fourth model adds two more variables that might also affect loan supply during the sample period, a House price index capturing the value of collateral and the growth of the market (Growth in the number of firms) as a proxy for the number of potential lending opportunities for banks.

We employ firm, industry and bank fixed effects to account for unobservable firm-level, industry-level and bank-level influences. ${ }^{17}$ We address the potential endogeneity problem associated with, among other things, regressing a quantity on its price by using lagged values of the explanatory variables as instruments.

Our simultaneous equations system shown in (1), (2) and (3) and the three alternative specifications, are estimated as a switching regression model using a full information maximum likelihood (FIML) routine with fixed effects. Based on the results from the disequilibrium model, a firm is defined as financially constrained in year $t$ if the probability that the desired amount of bank credit in year $t$ exceeds the maximum amount of credit available in the same year is greater than 0.5. Following Gersovitz (1980), the probability that a firm will face a financial constraint in year $t$ is expressed as:

$$
\operatorname{Pr}\left(\operatorname{loan}_{i t}^{d}>\operatorname{loan}_{i t}^{s}\right)=\operatorname{Pr}\left(X_{i t}^{d} \beta^{d}+u_{i t}^{d}>X_{i t}^{s} \beta^{s}+u_{i t}^{s}\right)=\Phi\left(\frac{X_{i t}^{d} \beta^{d}-X_{i t}^{s} \beta^{s}}{\sigma}\right)
$$

where $X_{i t}^{d}$ and $X_{i t}^{s}$ denote the variables that determine a firm's loan demand and the maximum amount of credit available to a firm, respectively. The error terms are assumed to be distributed normally, $\sigma^{2}=\operatorname{var}\left(u_{i t}^{d}-u_{i t}^{s}\right)$, and $\Phi($.$) is a standard normal distribution$

\footnotetext{
${ }^{17}$ Firms are categorized into 14 industries.
} 
function. Since $E\left(\operatorname{loan}_{i t}^{d}\right)=X_{i t}^{d} \beta^{d}$ and $E\left(\operatorname{loan}_{i t}^{s}\right)=X_{i t}^{s} \beta^{s}, \operatorname{Pr}\left(\operatorname{loan}_{i t}^{d}>\operatorname{loan}_{i t}^{s}\right)>0.5$, if and only if $E\left(\operatorname{loan}_{i t}^{d}\right)>E\left(\operatorname{loan}_{i t}^{s}\right)$. This specification will also allow us to distinguish between those borrowers that get less in bank loans than they need (partially constrained) and those that don't get any loans at all (fully constrained).

In order to make our identification strategy of unconstrained vs. constrained firms as accurate as possible we utilize two criteria:

- Firms are classified as "constrained" (or "unconstrained") only if they meet this classification standard in all four of the disequilibrium model specifications. The degree of coincidence here is $90 \%$ meaning that $90 \%$ of the cases the firms are classified the same in all four models (i.e., this reduces the sample size by 10\%).

- Following Petersen and Rajan (1994) and Kaplan and Zingales (1997) an accounting ratio filter is applied that excludes from the sample of constrained firms those that fall into all three of the following categories: the highest quartile of sales growth, the highest quartile of inventory growth, and the highest quartile of debt (external funding) to total assets. Although accounting ratios may be good proxies for financing constraints, they can be affected by endogeneity and identification problems. Petersen and Rajan (1994) and Kaplan and Zingales (1997) argue that these problems are most acute for observations containing extreme values for these ratios. So we exclude these firms in order to better capture firms that are truly “constrained”. ${ }^{18}$ We note, however, that this accounting filter only excludes about $1 \%$ of the total number of observations and that our results are not significantly different without their exclusion (i.e., without applying this

\footnotetext{
${ }^{18}$ Kaplan and Zingales (1997) note, for example that "if both investment and cash flow grow at a rate similar to the growth rate of sales, then part of the comovement of investment and cash flow may be due to a scale factor. This effect would bias the estimates of the investment-cash flow sensitivity toward one, particularly in firms with higher annual growth rates.” Consequently, Kaplan and Zingales only report the results of regressions that exclude firm-years with more than 30 percent sales growth (the upper quartile).
} 
filter). Likewise the inclusion or exclusion of these firms has no significant impact on the results from the second-stage regressions which test the sensitivity of investment to alternative sources of external funding ${ }^{19}$.

\section{III.C. Estimation of the Relative Dependence on Bank Loans versus Trade Credit}

Using the classifications from our disequilibrium model we can now turn to our predictability tests that analyze the sensitivity of investment to the two key sources of SME external finance, bank loans and trade credit. (Again, we only include the firms that passed the two criteria described above.) If constrained SMEs turn to trade credit as an alternative to bank loans, then we should find that trade credit predicts investment but bank loans do not. However, for unconstrained firms who have access to bank loans we should find that bank loans predict investment but trade credit does not. Since our dataset consists of cross-section and time series firm-level observations, the predictability regressions include fixed effects ( $f$ ). The empirical specification follows the HoltzEakin et al. (1988) approach on predictability tests for panel data. Given $N$ firms $(i=1, \ldots, N), t$ time periods $(t=1, \ldots, T)$, and firm-specific fixed effects $\left(f_{i}\right)$, bank loans specifically "bank loans/total liabilities” - will predict investment if two conditions are met:

\footnotetext{
${ }^{19}$ Even if the results are similar when this criterion is applied, this filter serves as a good test for the potential impact of the so-called "flypaper effect" in our second-stage estimation. As shown by Hines and Thaler (1995), in the context of firm financing constraints, the flypaper effect refers to the possibility that some firms are conservative in their investment decision-making, and they invest only when they have the cash flow to do so.
} 
i) the bank loans ratio is statistically significant in a time-series regression in first differences of firm investment:

$\left(\text { Capital exp enditure }_{i t} / \text { capital }_{i t-1}\right)_{t}-\left(\text { Capital exp enditure }_{i t} / \text { capital }_{i t-1}\right)_{t-1}=\alpha_{0}$

$+\sum_{j=1}^{m} \beta_{j}\left[\left(\text { Capital expenditure }_{i t} / \text { capital }_{i t-1}\right)_{t-j}-\left(\text { Capital expenditure }_{i t} / \text { capital }_{i t-1}\right)_{t-j-1}\right]$

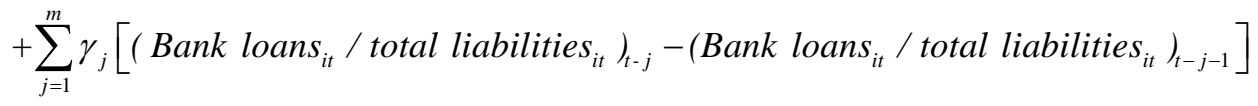

$+\psi_{t} f_{i}+\left(u_{i t}-u_{i t-1}\right)$

ii) and, the investment variable is not significant when it is included in a time-series regression in first differences of the bank loans ratio:

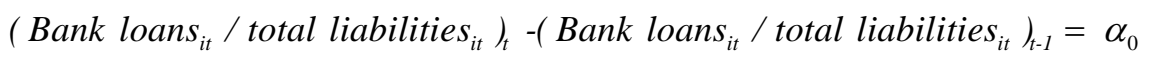
$+\sum_{j=1}^{m} \beta_{j}\left[\left({\text { Bank } \text { loans }_{i t} / \text { total liabilities }}_{i t}\right)_{t-j}-\left(\text { Bank loans }_{i t} / \text { total liabilities }_{i t}\right)_{t-j-1}\right]$

$\left.+\sum_{j=1}^{m} \gamma_{j}\left[\text { Capital expenditure }_{i t} / \text { capital }_{i t-1}\right)_{t-j}-\left(\text { Capital expenditure }{ }_{i t} / \text { capital }_{i t-1}\right)_{t-j-1}\right]$ $+\psi_{t} f_{i}+\left(u_{i t}-u_{i t-1}\right)$

If instead, the situation is reversed so that the $\sum \gamma_{i}$ in the first set of regressions is not significant while in the second set $\sum \beta_{i}$ is significant, then investment predicts bank loans. Further, if bank loans variable in equation (5) and the firm investment variable in equation (6) are both significant, then there will be predictability in both directions and it is likely that a third factor is driving both the evolution of firm investment and bank loans.

The variables are lagged (with $m$ being the number of lags) given that these relationships are not necessarily contemporary but likely reflect long-term effects (Rosseau and Wachtel 1998). An Augmented Dickey-Fuller (ADF) procedure is applied as a test for unit roots. First differencing the variables was sufficient to achieve stationarity. This is also important because the specification in (5) and (6) introduces a problem of simultaneity because the error term is correlated with the regressor. To 
address this, a two-stage least squares (2SLS) instrumental variables procedure with a time-varying set of instruments is used to estimate the model in first differences. As for the number of lags, the dependent variables are regressed on the two-year lagged explanatory variables. We also follow Holtz-Eakin et al. (1998) to determine the optimal lag length, which is given by the value of $m$ that minimizes the sum of the squared residuals ( $m=2$ in our case).

The vector of instrumental variables used to identify the parameters of the equations in first differences includes two lags of sales growth, cash flow and the ratio of

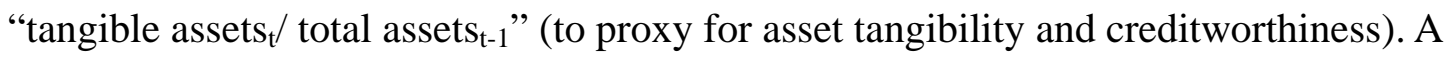
necessary condition for identification is that there are at least as many instrumental variables as other right-hand side variables. The standard Hansen test for identification is employed.

As control variables, the predictability equations include Interbank interest rates,

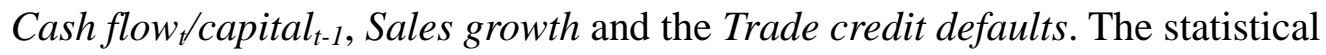
significance of the predictability test is measured using an F-test. The identification of the equation is improved when the individual effects and the lagged coefficients are stationary, so that the individual effects are eliminated. Since the results of standard Augmented-Dickey-Fuller tests indicate that first-differencing is sufficient to achieve stationarity, all variables are expressed in first-differences. 


\section{Results}

\section{IV.A. Disequilibrium model results}

The results of the four alternative specifications for the disequilibrium model estimated over the entire sample period are shown in Table II. All of the key variables show the expected sign. All of the specifications include bank and industry fixed effects. Taking the baseline model in column (1), sales over total assets and GDP growth are found to positively and significantly affect the demand for loans while the cash flow over total assets and the interest rate spread are negatively and significantly related to the demand for loans. Asset tangibility and GDP growth are found to be significant and positive determinants of loan supply while bank market power negatively affects the supply of loans to firms. As for the results in column (2) of Table II, they are very similar to the baseline specification but asset tangibility also enters the demand equation as a positive and significant explanatory factor and cash flow and sales are found to be (both positive and significant) determinants of loan supply. A set of relationship lending variables are included in column (3) and they are all found to be statistically significant determinants of loan supply. In particular, the age of the firm and the number of years of the bank-firm relationship are found to affect loan supply positively, while loan supply is lower for firms having multiple bank relationships as opposed to single relationships. Finally, the specification in column (4) adds the house price index and the growth of the number of firms and they are also found to affect loan supply positively and significantly.

Importantly, the estimated coefficients of the variables that are used in all the specifications do not vary significantly across them. The coincidence in the firms which are estimated to be constrained across the four specifications is $90 \%$. 
We alternatively allow the coefficients to vary across three periods to reflect the possibility that our supply and demand functions change (not shown for simplicity). The first period, 1994-2000, covers the recovery years after the credit crunch of the early 1990s; the second period, 1994-2006, captures the expansion years and the credit boom of the pre-crisis regime; and the third period, 2007-2010, captures the financial crisis. We use the most complete model in Table II - the one shown in column (4) - as a reference for the estimations across three periods. The coefficients appear particularly large for cash flow, loan interest spread and asset tangibility during the crisis period, showing the importance of these factors as determinants of loan demand and supply during periods of financial instability.

In order to verify that our empirical estimations of the disequilibrium model are reasonable we examine whether they show an increase in the fraction of firms that are constrained during the crisis (Table III) and whether constrained firms behave as we might have expected relative to unconstrained firms (Table IV). Table III shows in a year-by-year analysis that indeed the fraction of constrained firms increased during the crisis (2007-2010) based on the results column 4 of Table II and the additional filters of the quartile analysis described above. This result holds for alternative definitions of "constrained" including, partially constrained firms (those that received less in bank loans than they wanted) and fully constrained firms (those with a positive demand who received no bank loans). This is consistent with the general conclusion in the literature that SMEs faced a credit crunch during the current financial crisis (e.g., Jimenez et al. 2012, Popov and Udell 2011, and Puri, Rocholl and Steffen 2011). Unlike the current literature on the credit crunch in the SME market, we use on our European data a 
different methodology to separate demand from supply effects, i.e., we do not depend on survey questions or other data on whether firms applied for credit, nor do we depend on firm fixed effects for firms that borrow from multiple banks (which may or may not be analogous to single-bank firms). Our approach involves estimating demand and supply effects separately for each firm. Table IV shows that our key variables do indeed reflect differences between constrained and unconstrained firms as we would expect. In particular, capital expenditure and cash flow are stronger for unconstrained firms and cash flow-investment sensitivity is lower for unconstrained firms.

\section{[INSERT TABLE IV HERE]}

\section{IV.B. Firm financing and investment predictability tests: baseline results}

Now we turn to our main analysis - our tests on trade credit and financial constraints. These tests, shown in Table V, distinguish between unconstrained firms (Panel A), partially-constrained firms (Panel B) and fully-constrained firms (Panel C). A dummy variable distinguishing the pre-crisis (1994-2006) and crisis (2007-2010) periods is interacted with our investment (capital expenditure/capital) and bank funding (bank loans/total liabilities) variables. Again, the observations that did not pass the filters mentioned at the end of Section III.B were dropped out of the sample in all of our analyses. The results are shown without any crisis dummy or interaction (columns 1 to 4 in Table V), with the crisis dummy (columns 5 to 8 ) and with the crisis dummy and the interaction terms (columns 9 to 12). We note that the values from the Hansen test for over-identifying restrictions indicate that the instruments that we use are valid. 
For unconstrained firms in Panel A, we find that bank loans predict capital expenditure but capital expenditure is not found to be a significant determinant of bank loans. The coefficient is 0.51 suggesting that a $1 \%$ increase in the ratio of loans/total liabilities increases investment (capital expenditure/capital) by $0.51 \%$. This implies, for example, that a one standard deviation "bank loans/total liabilities" (i.e., 0.15) will produce a $7.65 \%$ change in investment. We also find that for unconstrained firms there is no significant change in the relationship between loans and investment from the pre-crisis to the crisis period as the dummy variable is not found to be statistically significant. Finally, trade credit (accounts payable/total liabilities) is not found to explain investment in unconstrained firms.

For partially-constrained firms (Panel B of Table V), "accounts payable/total liabilities" affects investment while "loans/total liabilities" do not. In particular, the coefficient of "accounts payable/total liabilities" is 0.19 suggests that one standard deviation in this variable (0.17) will increase investment by 3.23\%. Interestingly, there is no significant change in the relationship between trade credit and investment from the pre-crisis to the crisis years.

For fully-constrained firms (Panel C of Table V), only the relationship between accounts payable and capital expenditure can be analysed because, by definition, fully constrained firms do not get any bank loans. The results here show that "accounts payable/total liabilities" predicts investment and the coefficient (0.24) is even larger than for partially-constrained firms. Interestingly, the pre-crisis vs. crisis dummy shows a positive and significant sign in the case of fully-constrained firms which suggests that the 
dependence on trade credit for investment is even more important for constrained firms during crisis years.

[INSERT TABLE V HERE]

\section{IV.C. Firm financing and investment predictability tests: breakdown for different time periods}

In order to further explore the changes in the relationship between external firm funding and investment during the crisis years, we split the estimations for the two periods (1994-2006 and 2007-2010) ${ }^{20}$ This allows us to check whether the findings relationships in Table $\mathrm{V}$ hold for the periods before and during the crisis and whether they change in magnitude. The results are not shown for simplicity but the main findings are as follows: "Bank loans/total liabilities" predict investment at unconstrained firms both before and during the crisis. However, during the crisis, sensitivity of investment to bank loans decreased for unconstrained firms (but is still significant at the $10 \%$ level). This is consistent with the effects of the credit crunch. This result also appears for partially constrained firms. This is consistent with the effects of a credit crunch. This also holds for partially constrained firms (i.e., decreased sensitivity but still significant at the $10 \%$ level). The results from the pre-crisis to the crisis years for fully-constrained firms suggest that the relationship between "accounts payable/total liabilities" and investment shown in Table $\mathrm{V}$ is even larger during the crisis years (0.27) than during the pre-crisis

\footnotetext{
${ }^{20}$ We have also estimated the main equations for the earlier post-crunch period (1994-2000). The results are similar to the pre-crunch period of 1994-2006 although the coefficients showing loan-investment and trade-credit investment sensitivities are of a lesser magnitude. For the sake of simplicity we only report the results for the 1994-2006 and 2007-2008 periods. The results of the 1994-2000 period are available upon request to the authors.
} 
years (0.22). This suggests a particularly important role for trade credit in financing investment for firms who do not have access to bank loans during times of financial stress.

As an additional robustness check we use an alternative measure of trade credit financing substituting the number of days that trade credit is extended to firms for “accounts payable/total liabilities”. The results are very similar.

As a final robustness check, the predictability tests were also estimated (not shown) excluding those firms showing a cash-flow investment correlation higher than 90\% since these firms may be particularly conservative in their investment decisionmaking investing only when they have the cash flow to do so (Hines and Thaler, 1995). Our main findings hold when these firms are excluded.

Taken together our results provide the strongest results yet in the literature that trade credit provides the most important alternative lending technology to bank loans for credit constrained SMEs and that trade credit plays an especially vital role during a credit crisis. Unlike prior studies that were confined to analyzing the behaviour of trade credit during macro shocks either from a large firm perspective (e.g., Calomiris, Himmelberg and Wachtel et al. 1995, Garcia-Appendini and Montoriol-Garriga 2013) or confined to analyzing aggregated SME data (Taketa and Udell 2007), we are able to analyze the role of trade credit using firm-level data. Although our results do not permit us to establish if bank loans and trade credit are substitutes or complements for firm financing, we find that unconstrained firms depend more on bank financing to fund capital expenditure while constrained firms depend more on trade credit, and that the magnitude of these effects increases during the crisis for fully-constrained firms. 


\section{Conclusions}

There is a growing literature on the effect of the financial crisis on firm access to finance. Virtually all of the literature on the most vulnerable firms, SMEs, has been conducted in Europe because of a lack of firm-level data on SMEs in the U.S. Unlike large firms, SMEs do not have access to the capital markets and thus have a much more limited menu of alternative sources of external finance. Despite this vulnerability, there has been virtually no research on how SMEs changed their dependence on alternative sources of external finance during the financial crisis. Practically speaking there are only two economically important alternatives for SMEs across most of the world: bank loans and trade credit.

In this paper we analyse whether trade credit provided an alternative source of external finance to SMEs during the current crisis using firm level panel data on over 40,000 Spanish SMEs. Like other recent studies using European SME data we find significant evidence of a general credit crisis in the SME sector during the crisis. But, for the first time, we also find that SME access to these two alternative sources of external finance varies across firms and that it changed during the crisis in interesting ways. Specifically, we find that credit constrained SMEs depend on trade credit, but not bank loans, to finance capital expenditure -- and that the intensity of this dependence increased during the financial crisis. Unconstrained firms, in contrast, are dependent on banks loans but not trade credit. This suggests that trade credit was an important mechanism that helped some SMEs cope with the credit crisis induced by this crisis. In other words, 
we find evidence that trade creditors play a role in the SME sector as lenders of last resort and this role becomes more important during a credit crisis.

\section{References}

Albertazzi, U., and D.J.Marchetti, 2010. "Credit Supply, Flight to Quality and Evergreening: An Analysis of Bank-firm Relationships after Lehman.” Temi di Discussione (Working Paper) 756 Banca d’Italia.

Almeida, H. and M. Campello, 2007. "Financial Constraints, Asset Tangibility, and Corporate Investment.” Review of Financial Studies 20: 1429-1460.

Almeida, H., Campello, M., Laranjeira, B., and S. Weisbenner, 2012. Corporate Debt Maturity and the Real Effects of the 2007 Credit Crisis. Critical Finance Review, 1: 3-58.

Atanasova, C.V. and N. Wilson, 2004. "Disequilibrium in the UK Corporate Loan Market.” Journal of Banking and Finance 28: 595-614.

Berger, A.N., Udell, G.F., 1995. Relationship lending and lines of credit in small firm finance, Journal of Business, 68: 351-382.

Berger, A.N., and Udell, G.F., 1998. "The Economics of Small Business Finance: The Role of Private Equity and Debt Markets in the Financial Growth Cycle.” Journal of Banking and Finance 22: 613-673.

Biais, B., and C. Gollier, 1997. “Trade Credit and Credit Rationing.” Review of Financial Studies 10: 903-937.

Boissay, F., and Gropp, R., 2007, “Trade Credit Defaults and Liquidity Provision by Firms.” ECB working paper.

Brechling, F.P.R., and R. G. Lipsey. “Trade Credit and Monetary Policy.” Economic Journal 73(4): 618-641.

Burkart, M., and T. Ellingsen, 2004, "In-Kind Finance: A Theory of Trade Credit," The American Economic Review, 94(3): 569-590.

Calomiris, C., Himmelberg, C. and P. Wachtel, 1995. "Commercial Paper, Corporate Finance, and the Business Cycle: A Microeconomic Approach." Carnegie-Rochester Series on Public Policy 42: 203-250.

Carbó, S., Rodríguez, F. and G. F. Udell, 2009. "Bank Market Power and SME Financing Constraints.” Review of Finance 13: 309-340. 
Carey, M., Prowse, S., Rea, J., and Udell, G.F., 1993, The Economics of Private Placements: A New Look, Financial Markets, Institutions and Instruments 2.

Cetorelli, N. and M. Gambera, 2001. "Banking Market Structure, Financial Dependence and Growth: International Evidence from Industry Data.” Journal of Finance 56, 617-48/

Choi, W.G., and Y. Kim, 2005. "Trade Credit and the Effect of Macro-Financial Shocks: Evidence from U.S. Panel Data.” Journal of Financial and Quantitative Analysis 40: 897925.

Cook, L., 1999. “Trade Credit and Bank Finance: Financing Small Firms in Russia.” Journal of Business Venturing 14: 493-518.

Cuñat, V., 2007, “Trade Credit: Suppliers as Debt Collectors and Insurance Providers.” Review of Financial Studies 20: 491-527.

de Haas, R. and I.V. van Horen, 2010. "Internal Capital Markets and Lending by Multinational Bank Subsidiaries.” Journal of Financial Intermediation 19(1): 1-25.

Demirgüç-Kunt, A. and V. Maksimovic, 2002, "Firms as Financial Intermediaries: Evidence from Trade Credit Data.” University of Maryland working paper.

Demiroglu, C., C. James and A. Kizilaslan, 2012. "Bank Lending Standards and Access to Lines of Credit.” Journal of Money, Credit and Banking, 4 (6): 1063-1089

Duchin, R., O. Ozbas, B.A. Sensoy, 2010. “Costly External Finance, Corporate Investment, and the Subprime Mortgage Credit Crisis.” Journal of Financial Economics 97, 418-435.

Garcia-Appendini, M.E., 2006. “Signalling in the Credit Markets: The Case of Trade Credit.” Mimeo, Universitat Pompeu Fabra.

Garcia-Appendini, M.E., and J. Montoriol-Garriga, 2013. "Firms as Liquidity Providers: Evidence from the 2007-2008 Financial Crisis.” Journal of Financial Economics 109: 272-291.

Gersovitz, M., 1980. “Classification Probabilities for the Disequilibrium Model.” Journal of Econometrics 41: 239-246.

Giannetti, M., M. Burkart, and T. Ellingsen, 2011, "What You Sell Is What You Lend? Explaining Trade Credit Contracts.” Review of Financial Studies 24: 1261-1298.

Hines, J.R. Jr. and R. Thaler, 1995. “The Flypaper Effect.” Journal of Economic Perspectives 9: 217-226. 
Holtz-Eakin D., Newey W. and H. Rosen, 1998. “Estimating Vector Autoregressions with Panel Data.” Econometrica 56: 1371-95.

Illueca, M., L. Norden and G.F. Udell, 2014. "Liberalization, Bank Governance, and Risk Taking.” Review of Finance, forthcoming.

Ivashina, V. and D. Scharfstein, 2010. "Bank lending during the financial crisis of 2008”, Journal of Financial Economics 97: 319-338.

Iyer, R., S. Lopes, J-L Peydro, and A. Schoar, 2010. "Interbank Liquidity Crunch and the Firm Credit Crunch: Evidence from the 2007-2009 Crisis.” European Central Bank Working Paper.Jaffee, 1971

Jimenez, G, S. Ongena, J. Peydro and J. Saurina, 2011. "Monetary Policy and the Credit Crunch: Identifying Simultaneously the Bank Lending and Balance Sheet Channels.” American Economic Review (forthcoming).

Kaplan, S. and L. Zingales, 1997. "Do Financing Constraints Explain why Investment is Correlated with Cash Flow?” Quarterly Journal of Economics 112: 169-215.

Maddala, G.S. and F.D. Nelson, 1974. "Maximum Likelihood Methods for Models of Markets in Disequilibrium.” Econometrica 42: 1013-1030.

Klapper, L., L. Laeven and R. Rajan, 2011. “Trade Credit Contracts.” The World Bank Policy Research Workin Paper 5726.

Love, I., L. Preve and V. Sarria-Allende, 2007. “Trade Credit and Bank Credit: Evidence from Recent Financial Crises.” Journal of Financial Economics 83: 453-69.

Maddala, G.S., 1980. “Disequilibrium, Self-selection and Switching Models.” Social Science Working Paper 303. California Institute of Technology, February.

Marotta, G., 1996. "Does Trade Credit Redistribution Thwart Monetary Policy? Evidence from Italy.” mimeograph.

Meltzer, A.H., 1960. “Mercantile Credit, Monetary Policy, and Size of Firms.” Review of Economics and Statistics 42: 429-437.

McMillan, J. and Woodruff, C., 1999. "Interfirm Relationships and Informal Credit in Vietnam.” Quarterly Journal of Economics 98: 1285-1320.

Nielsen, J. H., 2002. “Trade Credit and the Bank Lending Channel.” Journal of Money, redit, and Banking , 34: 226-253 
Ogawa, K. and K. Suzuki, 2000. "Demand for Bank Loans and Investment Under Borrowing Constraints: A Panel Study of Japanese Firm Data,” Journal of the Japanese and International Economics 14: 1-21.

Ongena, S., A. Popov, and G.F. Udell, 2013. "When the Cat's Away the Mice Will Play.” Journal of Financial Economics, 108(3), pages 727-750.

Ono, M., 2001. "Determinants of Trade Credit in the Japanese Manufacturing Sector.” Journal of the Japanese and International Economies 15: 160-177.

Peek, J., and E. Rosengren, 1997. "The International Transmission of Financial Shocks: The Case of Japan.” American Economic Review 87: 495-505.

Perez, S.J., 1998. “Testing for Credit Rationing: An Application of Disequilibrium Econometrics.” Journal of Macroeconomics 20: 721-739.

Petersen, M. A. and R. G. Rajan, 1994. "The Benefits of Lending Relationships: Evidence from Small Business Data.” Journal of Finance 1: 3-37.

Petersen, M. A., and R. G. Rajan, 1997. “Trade Credit: Theories and Evidence,” The Review of Financial Studies, 10(3): 661-691.

Popov, A., and G.F. Udell, 2012. "Cross-Border Banking, Credit Access, and the Financial Crisis.” Journal of International Economics 87: 147-161.

Presbitero, A., G.F. Udell and A. Zazzaro, 2014. "Bank Organizational Structure and the Credit Crunch.” Journal of Money, Credit and Banking, 46: 53-85.

Puri, M., J. Rocholl and S. Steffen, 2011. "Global Retail Lending in the Aftermath of the U.S. Financial Crisis: Distinguishing between Supply and Demand Effects.” Journal of Financial Economics 100(3): 556-578.

Ramey, V.A., 1992. “The Source of Fluctuations in Money: Evidence from Trade Credit.” Journal of Monetary Economics 30: 171-193.

Rousseau, P.L. and P. Wachtel, 1998. "Financial Intermediation and Economic Performance: Historical Evidence from Five Industrialized Countries.” Journal of Money, Credit and Banking 30: 657-678.

Sealey, C.W., 1979. "Credit Rationing in the Commercial Loan Market: Estimates of a Structural Model Under Conditions of Disequilibrium.” Journal of Finance 34: 689-702.

Smith, J. K., 1987. “Trade Credit and Information Asymmetry,” Journal of Finance 42: 863-872. 
Steijvers, T., 2008. "Existence of Credit Rationing for SME's in the Belgian Corporate Bank Loan Market,” mimeo.

Taketa, K. and G.F. Udell, 2007. "Lending Channels and Financial Shocks: The Case of SME Trade Credit and the Japanese Banking Crisis.” Monetary and Economic Studies 25: $1-44$.

Tsuruta, D., 2003. "Bank Information Monopoly and Trade Credit: Does Only Bank Have Information?” University of Tokyo Working Paper.

Uchida, H., G.F. Udell and W. Watanabe, 2013. “Are Trade Creditors Relationship

Lenders?” Japan and the World Economy, 25: 24-38.

Udell, G.F., 2009. “How Will a Credit Crunch Affect Small Business Finance?” Federal Reserve Bank of San Francisco Economic Letter.

Uesugi, I., K. Sakai and G.M. Yamashiro, 2006. "Effectiveness of Credit Guarantees in the Japanese Loan Market.” RIETI Discussion Paper Series 06-E-004.

Whited, Toni and Guojun Wu, 2006. "Financial Constraints Risk.” Review of Financial Studies 19, 531-559.

Wilner, B.S., 2000. “The Exploitation of Relationships in Financial Distress: The Case of Trade Credit.” Journal of Finance 55: 153-178. 
TABLE I. VARIABLES: DESCRIPTIVE STATISTICS

The descriptive statistics in this table refer to the sample selection effectively used in the empirical analysis after applying the appropriate filters, as described in section III.B.

\begin{tabular}{|c|c|c|c|c|c|c|c|}
\hline VARIABLE & Mean & St Dev. & Median & Max & Min & $25 \%$ & $75 \%$ \\
\hline Capital expenditure $_{t} /$ capital $_{t-1}$ & 0.33 & 0.18 & 0.31 & 0.73 & 0.00 & 0.19 & 0.51 \\
\hline Bank loans & $5,632.4$ & $4,987.2$ & $5,139.7$ & $19,263.5$ & 0.00 & 639,6 & $12,386.2$ \\
\hline Banks loans/total liabilities & 0.21 & 0.15 & 0.19 & 0.75 & 0.00 & 0.08 & 0.49 \\
\hline Credit period & 27.11 & 17.18 & 26.52 & 89.18 & 10.04 & 14.16 & 65.99 \\
\hline Accounts payable / total liabilities & 0.31 & 0.17 & 0.28 & 0.59 & 0.00 & 0.16 & 0.48 \\
\hline Total assets & $9,694.2$ & $3,958.3$ & $7,153.26$ & $839,156.1$ & $1,116.3$ & $3,277.1$ & $759,215.3$ \\
\hline Tangible assets & $1,513.7$ & 639.28 & $1,386.4$ & $116,209.3$ & 31.23 & 753.4 & 1.380 .2 \\
\hline Cash flow & $1,253.8$ & 436.30 & $1,196.9$ & $10,596.3$ & 10,36 & 435.0 & $7,326.1$ \\
\hline Cash flow $_{t}$ capital $_{t-1}$ & 0.42 & 0.28 & 0.36 & 0.63 & 0.04 & 0.16 & 0.53 \\
\hline Sales & $18,630 . .3$ & $10,041.5$ & $16,215.6$ & $2,326,255.4$ & 231.23 & $6,153.3$ & $1,154,005.2$ \\
\hline Sales growth & 0.23 & 0.14 & 0.21 & 1.23 & 0.02 & 0.15 & 0.89 \\
\hline Interbank interest rates & 0.06 & 0.02 & 0.05 & 0.10 & 0.02 & 0.05 & 0.06 \\
\hline Loan interest spread & 0.01 & 0.003 & 0.01 & 0.07 & 0.001 & 0.007 & 0.05 \\
\hline Default risk & 4.29 & 2.16 & 4.15 & 10.33 & 0.86 & 3.31 & 8.74 \\
\hline Banks 'market power & 23.02 & 8.56 & 22.17 & 39.77 & 16.25 & 19.23 & 31.13 \\
\hline House price index & 8.96 & 3.34 & 8.45 & 21.32 & -8.9 & 5.61 & 19.05 \\
\hline $\begin{array}{c}\text { Market growth (growth of the number of } \\
\text { firms) }\end{array}$ & 6.79 & 2.31 & 6.36 & 15.31 & 2.42 & 4.27 & 12.11 \\
\hline Defaults in trade credit & 0.02 & 0.002 & 0.02 & 0.09 & 0.01 & 0.012 & 0.073 \\
\hline GDP growth & 0.02 & 0.01 & 0.02 & 0.05 & -0.03 & 0.015 & 0.043 \\
\hline Age of the firm & 10.71 & 3.74 & 10.47 & 62.7 & 0 & 4.17 & 38.26 \\
\hline Length (n. years relationship) & 6.54 & 2.58 & 6.22 & 24.3 & 0 & 2.93 & 17.32 \\
\hline Single vs. multiple bank relationships & 0.50 & 0.22 & 0.48 & 5 & 0 & 0.02 & 3.75 \\
\hline
\end{tabular}


TABLE II. ESTIMATED PARAMETERS OF THE DISEQUILIBRIUM MODEL

Switching regression model estimated by full information maximum likelihood (FIML) with firm fixed effects p-values in parenthesis

Standard errors are clustered at the firm level

\begin{tabular}{|c|c|c|c|c|}
\hline Demand for bank loans & (1) & (2) & (3) & (4) \\
\hline Sales/total assets(t-1) & $\begin{array}{c}0.6032 * * * \\
(0.000)\end{array}$ & $\begin{array}{c}0.5918 * * * \\
(0.000)\end{array}$ & $\begin{array}{c}0.6116 * * * \\
(0.000)\end{array}$ & $\begin{array}{c}0.6193 * * * \\
(0.000)\end{array}$ \\
\hline Cash-flow/total assets(t-1) & $\begin{array}{c}-2.0832 * * * \\
(0.000)\end{array}$ & $\begin{array}{c}-2.1365^{* * *} \\
(0.000)\end{array}$ & $\begin{array}{c}-2.0483^{* * *} \\
(0.000)\end{array}$ & $\begin{array}{c}-2.0613^{* * *} \\
(0.000)\end{array}$ \\
\hline Loan interest spread & $\begin{array}{c}-1.4021^{* * *} \\
(0.000)\end{array}$ & $\begin{array}{c}-1.3716^{* * *} \\
(0.000)\end{array}$ & $\begin{array}{c}-1.3813^{* *} \\
(0.000)\end{array}$ & $\begin{array}{c}-1.3918^{* * *} \\
(0.000)\end{array}$ \\
\hline GDP growth & $\begin{array}{c}0.0230 * * \\
(0.011)\end{array}$ & $\begin{array}{c}0.0211^{* *} \\
(0.015)\end{array}$ & $\begin{array}{c}0.0219 * * \\
(0.010) \\
\end{array}$ & $\begin{array}{c}0.0215^{* *} \\
(0.012)\end{array}$ \\
\hline Tangible fixed assets/total assets(t-1) & - & $\begin{array}{c}0.0374 * \\
(0.069) \\
\end{array}$ & $\begin{array}{c}0.0386^{*} \\
(0.053) \\
\end{array}$ & $\begin{array}{c}0.0374 * \\
(0.057) \\
\end{array}$ \\
\hline Default risk & - & $\begin{array}{c}0.00025 \\
(0.394) \\
\end{array}$ & $\begin{array}{c}0.00029 \\
(0.325) \\
\end{array}$ & $\begin{array}{c}0.00024 \\
(0.349) \\
\end{array}$ \\
\hline \multicolumn{5}{|l|}{ Supply of bank loans } \\
\hline Tangible fixed assets/total assets $(t-1)$ & $\begin{array}{c}2.4238 * * * \\
(0.000)\end{array}$ & $\begin{array}{c}2.4238 * * * \\
(0.000)\end{array}$ & $\begin{array}{c}2.4238 * * * \\
(0.000)\end{array}$ & $\begin{array}{c}2.3460 * * * \\
(0.000)\end{array}$ \\
\hline Banks’market power & $\begin{array}{c}-0.9704^{* * *} \\
(0.006)\end{array}$ & $\begin{array}{c}-0.9704^{* * *} \\
(0.006)\end{array}$ & $\begin{array}{c}-0.9704^{* * *} \\
(0.006)\end{array}$ & $\begin{array}{c}-0.9521^{* * *} \\
(0.006)\end{array}$ \\
\hline Default risk & $\begin{array}{c}0.000027 \\
(0.759) \\
\end{array}$ & $\begin{array}{c}0.000027 \\
(0.759)\end{array}$ & $\begin{array}{c}0.000029 \\
(0.759) \\
\end{array}$ & $\begin{array}{c}0.000031 \\
(0.704)\end{array}$ \\
\hline GDP growth & $\begin{array}{c}0.0799 * * \\
(0.013) \\
\end{array}$ & $\begin{array}{c}0.0799 * * \\
(0.013) \\
\end{array}$ & $\begin{array}{c}0.0799 * * \\
(0.013) \\
\end{array}$ & $\begin{array}{c}0.0816^{* *} \\
(0.017) \\
\end{array}$ \\
\hline Cash-flow/total assets(t-1) & - & $\begin{array}{c}0.9753^{* *} \\
(0.26) \\
\end{array}$ & $\begin{array}{c}0.9426 * * \\
(0.029) \\
\end{array}$ & $\begin{array}{c}0.9701^{* *} \\
(0.024) \\
\end{array}$ \\
\hline Sales/total assets(t-1) & - & $\begin{array}{c}0.4906^{* *} \\
(0.019) \\
\end{array}$ & $\begin{array}{c}0.5113^{* *} \\
(0.023) \\
\end{array}$ & $\begin{array}{c}0.4896 * * \\
(0.020) \\
\end{array}$ \\
\hline Age of the firm & - & - & $\begin{array}{c}0.2913 * * \\
(0.016) \\
\end{array}$ & $\begin{array}{c}0.2841^{* *} \\
(0.019) \\
\end{array}$ \\
\hline N. years relationship & - & - & $\begin{array}{c}0.1304 * * * \\
(0.009)\end{array}$ & $\begin{array}{c}0.1283^{* *} \\
(0.013) \\
\end{array}$ \\
\hline Single vs. multiple bank relationships & - & - & $\begin{array}{c}-0.0392 * \\
(0.057) \\
\end{array}$ & $\begin{array}{c}-0.0355 * \\
(0.051) \\
\end{array}$ \\
\hline House price index & - & - & - & $\begin{array}{c}0.0372 * \\
(0.076) \\
\end{array}$ \\
\hline Market growth (growth of the number of firms) & - & - & - & $\begin{array}{c}0.0026 * * \\
(0.041) \\
\end{array}$ \\
\hline Bank fixed effects & Yes & Yes & Yes & Yes \\
\hline Industry fixed effects & Yes & Yes & Yes & Yes \\
\hline Reciprocal of total assets in the loan demand equation & $\begin{array}{c}349,328.2^{* * *} \\
(0.000)\end{array}$ & $\begin{array}{c}364,231.4^{* * *} \\
(0.000)\end{array}$ & $\begin{array}{c}349,328.2^{* * *} \\
(0.000)\end{array}$ & $\begin{array}{c}356,288.6^{* * * *} \\
(0.000)\end{array}$ \\
\hline Reciprocal of total assets in the loan supply equation & $\begin{array}{c}225,361.4^{* * *} \\
(0.000) \\
\end{array}$ & $\begin{array}{c}229,183.0^{* * *} \\
(0.000) \\
\end{array}$ & $\begin{array}{c}225,361.4^{* * *} \\
(0.000) \\
\end{array}$ & $\begin{array}{c}230,291.4^{* * *} \\
(0.000)\end{array}$ \\
\hline S.D. of demand equation & $\begin{array}{c}1.5732 * * * \\
(0.000) \\
\end{array}$ & $\begin{array}{c}1.6233^{* * * *} \\
(0.000) \\
\end{array}$ & $\begin{array}{c}1.5732 * * * \\
(0.000) \\
\end{array}$ & $\begin{array}{c}1.5327 * * * \\
(0.000) \\
\end{array}$ \\
\hline S.D. of supply equation & $\begin{array}{c}0.4628 * * * \\
(0.000)\end{array}$ & $\begin{array}{c}0.4427 * * * \\
(0.000)\end{array}$ & $\begin{array}{c}0.4628 * * * \\
(0.000)\end{array}$ & $\begin{array}{c}0.4840 * * * \\
(0.000)\end{array}$ \\
\hline Correlation coefficient & $\begin{array}{c}0.7016 * * * \\
(0.000)\end{array}$ & $\begin{array}{c}0.7123^{* * *} \\
(0.000)\end{array}$ & $\begin{array}{c}0.7016^{* * *} \\
(0.000)\end{array}$ & $\begin{array}{c}0.6552 * * * \\
(0.000)\end{array}$ \\
\hline Log likelihood & 157,329 & 163,188 & 157,329 & 159,727 \\
\hline Observations & 528.317 & 528.317 & 528.317 & 528.317 \\
\hline Number of firms & 38.329 & 38.329 & 38.329 & 38.329 \\
\hline $\begin{array}{l}* \text { Statistically significant at } 10 \% \text { level } \\
* * \text { Statistically significant at } 5 \% \text { level } \\
* * * \text { Statistically significant at } 1 \% \text { level }\end{array}$ & & & & \\
\hline
\end{tabular}




\section{TABLE III. PERCENTAGE OF BORROWING CONSTRAINED FIRMS}

This table is based on the classification of firms that fall into each one of the categories in all the four specifications of the disequilibrium model in Table II. Additionally, using fully exogenous classifications such as those from Petersen and Rajan (1994) or Kaplan and Zingales (1997) -which are based on accounting ratios- we have excluded from the sample of constrained firms those that fall in the highest quartile of sales growth, the highest inventory growth, and the highest quartile of debt (external funding) to total assets. Fully-constrained firms are those that do not receive any lending but having a positive demand. Partially-constrained firms are those getting less credit that desired. Distressed firms are firms that go bankrupt in a given year.

\begin{tabular}{|c|c|c|c|c|c|}
\hline & $\begin{array}{c}\text { Fully- } \\
\text { constrained }\end{array}$ & $\begin{array}{c}\text { Partially- } \\
\text { constrained }\end{array}$ & $\begin{array}{c}\text { Constrained } \\
\text { (fully plus } \\
\text { partially } \\
\text { constrained) }\end{array}$ & $\begin{array}{c}\text { \% Constrained } \\
\text { firms among those } \\
\text { always active over } \\
\text { the sample period }\end{array}$ & $\begin{array}{c}\text { \% Distressed } \\
\text { firms }\end{array}$ \\
\hline $\begin{array}{c}\text { Entire period } \\
(1994-2010)\end{array}$ & 5.88 & 28.15 & 34.03 & 30.88 & 7.29 \\
\hline 1994 & 8.16 & 27.13 & 35.29 & 30.04 & 8.04 \\
\hline 1995 & 7.31 & 24.99 & 32.3 & 29.36 & 7.71 \\
\hline 1996 & 6.03 & 29.03 & 35.06 & 29.54 & 7.80 \\
\hline 1997 & 6.15 & 27.12 & 33.27 & 28.16 & 7.01 \\
\hline 1998 & 5.07 & 29.75 & 34.82 & 28.17 & 6.69 \\
\hline 1999 & 4.94 & 29.93 & 34.87 & 27.77 & 6.20 \\
\hline 2000 & 4.52 & 30.37 & 34.89 & 26.90 & 6.75 \\
\hline 2001 & 4.02 & 29.98 & 34,00 & 26.85 & 6.88 \\
\hline 2002 & 3.88 & 29.8 & 33.68 & 26.71 & 6.73 \\
\hline 2003 & 3.64 & 29.64 & 33.28 & 26.29 & 6.42 \\
\hline 2004 & 3.6 & 29.4 & 33,00 & 26.04 & 6.05 \\
\hline 2005 & 3.75 & 29.71 & 33.46 & 26.33 & 6.31 \\
\hline 2006 & 3.7 & 28.89 & 32.59 & 25.84 & 5.91 \\
\hline 2007 & 4.36 & 34.02 & 38.38 & 29.99 & 7.23 \\
\hline 2008 & 6.28 & 35.94 & 42.22 & 31.85 & 7.95 \\
\hline 2009 & 8.85 & 42.15 & 51,00 & 38.31 & 12.33 \\
\hline 2010 & 12.31 & 48.32 & 60.63 & 46.15 & 14.31 \\
\hline & & & & & \\
\hline & & & & & \\
\hline & & & & & \\
\hline
\end{tabular}


TABLE IV. COMPARISON OF FIRMS BY FINANCING CONSTRAINT STATUS

\begin{tabular}{|c|c|c|c|c|c|c|c|}
\hline & $\begin{array}{c}\text { Fully- } \\
\text { constrained }\end{array}$ & $\begin{array}{c}\text { Partially- } \\
\text { constrained }\end{array}$ & Unconstrained & $\begin{array}{c}\text { All } \\
\text { firms }\end{array}$ & $\begin{array}{c}\text { Mean } \\
\text { differences } \\
\text { between } \\
\text { fully-and } \\
\text { partially } \\
\text { constrained } \\
\text { (p-value) }\end{array}$ & $\begin{array}{c}\text { Mean } \\
\text { differences } \\
\text { between } \\
\text { fully- } \\
\text { constrained } \\
\text { and } \\
\text { unconstraine } \\
\text { d (p-value) }\end{array}$ & $\begin{array}{c}\text { Mean } \\
\text { differences } \\
\text { between } \\
\text { partially- } \\
\text { constrained } \\
\text { and } \\
\text { unconstrained } \\
\text { (p-value) } \\
\end{array}$ \\
\hline \% over all firms & 5.88 & 28.15 & 65.97 & 100 & - & - & - \\
\hline $\begin{array}{c}\text { Capital expenditure }_{t} \\
\text { capital }_{t-1}\end{array}$ & 0.161 & 0.173 & 0.415 & 0.334 & 0.327 & 0.004 & 0.005 \\
\hline Cash flow $_{t} /$ capital $_{t-1}$ & 0.118 & 0.240 & 0.334 & 0.308 & 0.032 & 0.003 & 0.025 \\
\hline $\begin{array}{c}\text { (Cash } \text { flow }_{t}-\text { Capital } \\
\left.\text { expenditure }_{t}\right) / \text { capital }_{t-1}\end{array}$ & -0.079 & -0.064 & 0.118 & 0.061 & 0.087 & 0.013 & 0.016 \\
\hline Sales growth & 0.081 & 0.220 & 0.561 & 0.473 & 0.013 & 0.001 & 0.010 \\
\hline Inventory growth & -0.037 & 0.050 & 0.213 & 0.0131 & 0.008 & 0.002 & 0.005 \\
\hline $\begin{array}{c}\text { Cash flow-investment } \\
\text { correlation }\end{array}$ & 0.578 & 0.739 & 0.459 & 0.714 & 0.045 & 0.046 & 0.017 \\
\hline
\end{tabular}


TABLE V. FIRM FINANCING AND INVESTMENT PREDICTABILITY TESTS.

2SLS with instrumental variables (p-values in parentheses) and firm fixed effects. Standard errors are clustered at the firm level

\begin{tabular}{|c|c|c|c|c|c|c|c|c|c|c|c|c|}
\hline \multicolumn{13}{|c|}{ PANEL A. UNCONSTRAINED FIRMS } \\
\hline & (1) & (2) & (3) & (4) & (5) & (6) & (7) & $(8)$ & (9) & (10) & (11) & $(12)$ \\
\hline & $\begin{array}{c}\text { Capital } \\
\text { expenditure }_{t} \\
{\text { / } \text { capital }_{t-1}}\end{array}$ & $\begin{array}{c}\text { Bank } \\
\text { loans/total } \\
\text { liabilities }\end{array}$ & $\begin{array}{c}\text { Capital } \\
\text { expenditure }_{t} \\
{\text { / } \text { capital }_{t-1}}\end{array}$ & $\begin{array}{c}\text { Accounts } \\
\text { payable/ } \\
\text { total } \\
\text { liabilities }\end{array}$ & $\begin{array}{c}\text { Capital } \\
\text { expenditure }_{t} \\
{\text { / } \text { capital }_{t-1}}\end{array}$ & $\begin{array}{c}\text { Bank } \\
\text { loans/total } \\
\text { liabilities }\end{array}$ & $\begin{array}{c}\text { Capital } \\
\text { expenditure }_{t} \\
{\text { / } \text { capital }_{t-1}}\end{array}$ & $\begin{array}{l}\text { Accounts } \\
\text { payable/ } \\
\text { total } \\
\text { liabilities }\end{array}$ & $\begin{array}{c}\text { Capital } \\
\text { expenditure }_{t} \\
{\text { / } \text { capital }_{t-1}}\end{array}$ & $\begin{array}{c}\text { Bank } \\
\text { loans/total } \\
\text { liabilities }\end{array}$ & $\begin{array}{c}\text { Capital } \\
\text { expenditure }_{t} \\
\text { capital }_{t-1}\end{array}$ & $\begin{array}{l}\text { Accounts } \\
\text { payablel } \\
\text { total } \\
\text { liabilities } \\
\end{array}$ \\
\hline Constant & $\begin{array}{c}0.2957^{*} \\
(0.114) \\
\end{array}$ & $\begin{array}{l}0.1705^{*} \\
(0.081)\end{array}$ & $\begin{array}{l}0.3205 \\
(0.119)\end{array}$ & $\begin{array}{l}0.1462 * \\
(0.071)\end{array}$ & $\begin{array}{l}0.3086^{*} \\
(0.126)\end{array}$ & $\begin{array}{l}0.1682^{*} \\
(0.080)\end{array}$ & $\begin{array}{l}0.3105 \\
(0.117) \\
\end{array}$ & $\begin{array}{l}0.1326^{*} \\
(0.074)\end{array}$ & $\begin{array}{c}0.3102 * \\
(0.113) \\
\end{array}$ & $\begin{array}{l}0.1755^{*} \\
(0.079)\end{array}$ & $\begin{array}{l}0.3072 \\
(0.108)\end{array}$ & $\begin{array}{l}0.1460 * \\
(0.072)\end{array}$ \\
\hline Dependent variable $t_{t-1}$ & $\begin{array}{l}0.3086^{*} \\
(0.127) \\
\end{array}$ & $\begin{array}{l}0.2713^{*} \\
(0.121) \\
\end{array}$ & $\begin{array}{l}0.2075^{*} \\
(0.091) \\
\end{array}$ & $\begin{array}{l}-0.3228 \\
(0.205) \\
\end{array}$ & $\begin{array}{l}0.3102^{*} \\
(0.121) \\
\end{array}$ & $\begin{array}{l}0.2710^{*} \\
(0.136) \\
\end{array}$ & $\begin{array}{l}0.2061^{*} \\
(0.092) \\
\end{array}$ & $\begin{array}{l}-0.3261 \\
(0.204) \\
\end{array}$ & $\begin{array}{l}0.3035 * \\
(0.131) \\
\end{array}$ & $\begin{array}{l}0.2708^{*} \\
(0.120) \\
\end{array}$ & $\begin{array}{l}0.2056^{*} \\
(0.091) \\
\end{array}$ & $\begin{array}{l}-0.3093 \\
(0.204) \\
\end{array}$ \\
\hline (Capital expenditure ${ }_{t} /$ capital $\left._{t-1}\right)_{t-1}$ & - & $\begin{array}{l}0.0717 \\
(0.052)\end{array}$ & - & $\begin{array}{l}0.0424 \\
(0.152)\end{array}$ & - & $\begin{array}{l}0.0715 \\
(0.052)\end{array}$ & - & $\begin{array}{l}0.0422 \\
(0.143)\end{array}$ & - & $\begin{array}{l}0.0717 \\
(0.061)\end{array}$ & - & $\begin{array}{l}0.0407 \\
(0.118)\end{array}$ \\
\hline Pre-crisis (1994-2006) vs. crisis (2007-2010) dummy & - & - & - & 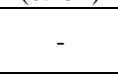 & $\begin{array}{l}-0.0263 \\
(0.189) \\
\end{array}$ & $\begin{array}{l}-0.0182 \\
(0.266) \\
\end{array}$ & $\begin{array}{l}-0.0044 \\
(0.213) \\
\end{array}$ & $\begin{array}{l}0.0032 \\
(0.126) \\
\end{array}$ & $\begin{array}{l}-0.0262 \\
(0.220) \\
\end{array}$ & $\begin{array}{l}-0.0016 \\
(0.169) \\
\end{array}$ & $\begin{array}{l}-0.0029 \\
(0.224) \\
\end{array}$ & $\begin{array}{l}-0.0102 \\
(0.183) \\
\end{array}$ \\
\hline $\begin{array}{c}\left.\text { (Capital expenditure } / \text { capital }_{t-1}\right)_{t-1} \text { X pre-crisis (1994-2006) } \\
\text { vs. crisis }(2007-2010) \text { dummy }\end{array}$ & - & - & - & - & - & - & - & - & - & $\begin{array}{l}-0.0417 \\
(0.218)\end{array}$ & - & $\begin{array}{l}0.0073 \\
(0.038)\end{array}$ \\
\hline Bank loans/total liabilities ${ }_{t-1}$ & $\begin{array}{c}0.5161 * * \\
(0.064)\end{array}$ & - & - & - & $\begin{array}{c}0.4890^{* *} \\
(0.085)\end{array}$ & - & - & - & $\begin{array}{c}0.4906^{* *} \\
(0.071)\end{array}$ & - & - & - \\
\hline $\begin{array}{c}\text { Bank loans/total liabilities }_{t-1} \text { X pre-crisis }(1994-2006) \text { vs. } \\
\text { crisis }(2007-2010) \text { dummy }(0,1)\end{array}$ & - & - & - & - & - & - & - & - & $\begin{array}{l}0.0928 \\
(0.132)\end{array}$ & - & - & - \\
\hline (Accounts payable/ total liabilities) ${ }_{t-1}$ & - & - & $\begin{array}{l}0.1207 \\
(0.114) \\
\end{array}$ & - & - & - & $\begin{array}{l}0.1232 \\
(0.118) \\
\end{array}$ & - & - & - & $\begin{array}{l}0.1228 \\
(0.102) \\
\end{array}$ & - \\
\hline 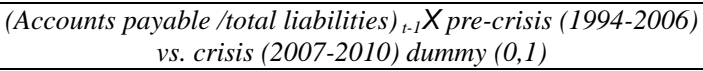 & - & - & $\begin{array}{c}-0.0054 \\
(0.014)\end{array}$ & - & - & - & $\begin{array}{c}-0.0064 \\
(0.014)\end{array}$ & - & - & - & $\begin{array}{l}-0.0067 \\
(0.014) \\
\end{array}$ & - \\
\hline Interbank interest rates & $\begin{array}{c}-0.1511^{*} \\
(0.068)\end{array}$ & $\begin{array}{c}-0.0851^{* *} \\
(0.031)\end{array}$ & $\begin{array}{c}-0.1262^{* *} \\
(0.047)\end{array}$ & $\begin{array}{l}-0.2329 \\
(0.214)\end{array}$ & $\begin{array}{c}-0.1611^{*} \\
(0.064)\end{array}$ & $\begin{array}{c}-0.0839 * * \\
(0.037)\end{array}$ & $\begin{array}{c}-0.1262^{* *} \\
(0.039)\end{array}$ & $\begin{array}{l}-0.2164 \\
(0.213)\end{array}$ & $\begin{array}{c}-0.1641^{*} \\
(0.071)\end{array}$ & $\begin{array}{c}-0.0813^{* *} \\
(0.027)\end{array}$ & $\begin{array}{c}-0.1260^{* *} \\
(0.040)\end{array}$ & $\begin{array}{l}-0.2153 \\
(0.235)\end{array}$ \\
\hline Cash flow f $_{\text {capital }}{ }_{t-1}$ & $\begin{array}{c}0.2178^{* *} \\
(0.016)\end{array}$ & $\begin{array}{l}0.1325 \\
(0.128)\end{array}$ & $\begin{array}{c}0.1877^{* *} \\
(0.016)\end{array}$ & $\begin{array}{l}-0.2326 \\
(0.124)\end{array}$ & $\begin{array}{c}0.2163^{* *} \\
(0.021)\end{array}$ & $\begin{array}{l}0.1374 \\
(0.119)\end{array}$ & $\begin{array}{c}0.1907 * * \\
(0.024)\end{array}$ & $\begin{array}{l}-0.2320 \\
(0.127)\end{array}$ & $\begin{array}{c}0.2123^{* *} \\
(0.021)\end{array}$ & $\begin{array}{l}0.1322 \\
(0.126)\end{array}$ & $\begin{array}{c}0.1973^{* *} \\
(0.018)\end{array}$ & $\begin{array}{l}-0.2257 \\
(0.129)\end{array}$ \\
\hline Sales growth & $\begin{array}{c}0.1362^{* *} \\
(0.039)\end{array}$ & $\begin{array}{l}0.3510 \\
(0.328)\end{array}$ & $\begin{array}{c}0.0603^{*} \\
(0.030)\end{array}$ & $\begin{array}{l}-0.2495 \\
(0.190) \\
\end{array}$ & $\begin{array}{c}0.1261^{* *} \\
(0.041)\end{array}$ & $\begin{array}{l}0.3532 \\
(0.318) \\
\end{array}$ & $\begin{array}{c}0.0612^{*} \\
(0.026)\end{array}$ & $\begin{array}{l}-0.2503 \\
(0.171) \\
\end{array}$ & $\begin{array}{c}0.1424^{* *} \\
(0.039)\end{array}$ & $\begin{array}{l}0.3507 \\
(0.304)\end{array}$ & $\begin{array}{c}0.0621^{*} \\
(0.023)\end{array}$ & $\begin{array}{l}-0.2531 \\
(0.179)\end{array}$ \\
\hline Defaults in trade credit & $\begin{array}{c}-0.1524^{*} \\
(0.071) \\
\end{array}$ & $\begin{array}{c}-0.1601^{*} \\
(0.071)\end{array}$ & $\begin{array}{c}-0.1531^{*} \\
(0.062)\end{array}$ & $\begin{array}{c}-0.1262^{*} \\
(0.059) \\
\end{array}$ & $\begin{array}{c}-0.1517^{*} \\
(0.072)\end{array}$ & $\begin{array}{c}-0.1614^{*} \\
(0.080)\end{array}$ & $\begin{array}{c}-0.1441^{*} \\
(0.061)\end{array}$ & $\begin{array}{c}-0.1263^{*} \\
(0.052) \\
\end{array}$ & $\begin{array}{c}-0.1506^{*} \\
(0.065)\end{array}$ & $\begin{array}{c}-0.1589^{*} \\
(0.072)\end{array}$ & $\begin{array}{c}-0.1417^{*} \\
(0.061)\end{array}$ & $\begin{array}{c}-0.1283^{*} \\
(0.062) \\
\end{array}$ \\
\hline$R^{2}($ first-stage $)$ & 0.86 & 0.84 & 0.79 & 0.88 & 0.87 & 0.82 & 0.80 & 0.86 & 0.87 & 0.86 & 0.81 & 0.90 \\
\hline F-test for overall significance (p-value) & 0.08 & 0.12 & 0.16 & 0.32 & 0.10 & 0.14 & 0.12 & 0.41 & 0.10 & 0.13 & 0.16 & 0.46 \\
\hline Hansen test (p-value) & 0.135 & 0.141 & 0.151 & 0.181 & 0.133 & 0.144 & 0.149 & 0.164 & 0.136 & 0.141 & 0.152 & 0.179 \\
\hline Number of observations & 217,742 & 217,742 & 217,742 & 217,742 & 217,742 & 217,742 & 217,742 & 217,742 & 217,742 & 217,742 & 217,742 & 217,742 \\
\hline
\end{tabular}




\section{PANEL B. PARTIALLY-CONSTRAINED FIRMS}

\begin{tabular}{|c|c|c|c|c|c|c|c|c|c|c|c|c|}
\hline & (1) & (2) & (3) & (4) & (5) & (6) & (7) & $(8)$ & (9) & (10) & (11) & $(12)$ \\
\hline & $\begin{array}{c}\text { Capital } \\
\text { expenditure }_{t} \\
{\text { / } \text { capital }_{t-1}}\end{array}$ & $\begin{array}{c}\text { Bank } \\
\text { loans/total } \\
\text { liabilities }\end{array}$ & $\begin{array}{c}\text { Capital } \\
\text { expenditure }_{t} \\
{\text { / } \text { capital }_{t-1}}\end{array}$ & $\begin{array}{l}\text { Accounts } \\
\text { payable/ } \\
\text { total } \\
\text { liabilities } \\
\end{array}$ & $\begin{array}{c}\text { Capital } \\
\text { expenditure }_{t} \\
{\text { / } \text { capital }_{t-1}}\end{array}$ & $\begin{array}{c}\text { Bank } \\
\text { loans/total } \\
\text { liabilities }\end{array}$ & $\begin{array}{c}\text { Capital } \\
\text { expenditure }_{t} \\
{\text { / } \text { capital }_{t-1}}\end{array}$ & $\begin{array}{l}\text { Accounts } \\
\text { payable/ } \\
\text { total } \\
\text { liabilities } \\
\end{array}$ & $\begin{array}{c}\text { Capital } \\
\text { expenditure }_{t} \\
{\text { / } \text { capital }_{t-1}}\end{array}$ & $\begin{array}{c}\text { Bank } \\
\text { loans/total } \\
\text { liabilities }\end{array}$ & $\begin{array}{c}\text { Capital } \\
\text { expenditure/ }^{\prime} \text { capital }_{t-1}\end{array}$ & $\begin{array}{l}\text { Accounts } \\
\text { payable/ } \\
\text { total } \\
\text { liabilities }\end{array}$ \\
\hline Constant & $\begin{array}{c}0.2032 * \\
(0.098)\end{array}$ & $\begin{array}{c}0.1843^{* *} \\
(0.041)\end{array}$ & $\begin{array}{l}0.2512 * \\
(0.085)\end{array}$ & $\begin{array}{l}0.0641 \\
(0.156)\end{array}$ & $\begin{array}{l}0.2127^{*} \\
(0.084)\end{array}$ & $\begin{array}{c}0.1829 * * \\
(0.038)\end{array}$ & $\begin{array}{c}0.2346^{*} \\
(0.089)\end{array}$ & $\begin{array}{l}0.0653 \\
(0.151)\end{array}$ & $\begin{array}{c}0.1893^{*} \\
(0.107)\end{array}$ & $\begin{array}{c}0.1812^{* *} \\
(0.067)\end{array}$ & $\begin{array}{l}0.2532 * \\
(0.098)\end{array}$ & $\begin{array}{l}0.0623 \\
(0.155)\end{array}$ \\
\hline Dependent variable $t_{t-1}$ & $\begin{array}{l}0.2013^{*} \\
(0.088)\end{array}$ & $\begin{array}{l}0.6482 \\
(0.553) \\
\end{array}$ & $\begin{array}{l}0.1813^{*} \\
(0.080)\end{array}$ & $\begin{array}{l}-0.226^{*} \\
(0.118)\end{array}$ & $\begin{array}{l}0.2003^{*} \\
(0.082)\end{array}$ & $\begin{array}{c}0.6413 \\
(0.528) \\
\end{array}$ & $\begin{array}{l}0.1817^{*} \\
(0.078)\end{array}$ & $\begin{array}{c}-0.2201^{*} \\
(0.091)\end{array}$ & $\begin{array}{l}0.2008^{*} \\
(0.092)\end{array}$ & $\begin{array}{c}0.6473 \\
(0.550) \\
\end{array}$ & $\begin{array}{l}0.1816^{*} \\
(0.076)\end{array}$ & $\begin{array}{l}-0.214^{*} \\
(0.107)\end{array}$ \\
\hline$\left(\text { Capital expenditure }{ }_{t} \text { capital }_{t-1}\right)_{t-1}$ & - & $\begin{array}{l}0.3108 \\
(0.266)\end{array}$ & - & $\begin{array}{c}0.207 \\
(0.215) \\
\end{array}$ & - & $\begin{array}{l}0.3103 \\
(0.288)\end{array}$ & - & $\begin{array}{l}0.2026 \\
(0.215) \\
\end{array}$ & - & $\begin{array}{l}0.3139 \\
(0.290) \\
\end{array}$ & - & $\begin{array}{c}0.216 \\
(0.213) \\
\end{array}$ \\
\hline Pre-crisis (1994-2006) vs. crisis (2007-2010) dummy & - & - & - & - & $\begin{array}{l}-0.0061 \\
(0.218) \\
\end{array}$ & $\begin{array}{l}-0.0362 \\
(0.161) \\
\end{array}$ & $\begin{array}{l}-0.0254 \\
(0.235) \\
\end{array}$ & $\begin{array}{l}-0.0533 \\
(0.201) \\
\end{array}$ & $\begin{array}{l}-0.0562 \\
(0.228)\end{array}$ & $\begin{array}{l}-0.0295 \\
(0.273) \\
\end{array}$ & $\begin{array}{l}-0.0053 \\
(0.236) \\
\end{array}$ & \\
\hline 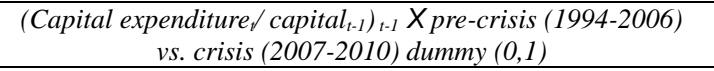 & - & - & - & - & - & - & - & - & - & $\begin{array}{l}0.0061 \\
(0.186)\end{array}$ & - & $\begin{array}{l}0.0768 \\
(0.155)\end{array}$ \\
\hline Bank loans/total liabilities $_{t-1}$ & $\begin{array}{l}0.1324 \\
(0.121) \\
\end{array}$ & - & - & - & $\begin{array}{l}0.1317 \\
(0.120)\end{array}$ & - & - & - & $\begin{array}{l}0.1314 \\
(0.129) \\
\end{array}$ & - & - & - \\
\hline $\begin{array}{c}\text { Bank loans/total liabilities }{ }_{\mathrm{t}-1} \text { X pre-crisis }(1994-2006) \text { vs. } \\
\text { crisis }(2007-2010) \text { dummy }(0,1)\end{array}$ & - & - & - & - & - & - & - & - & $\begin{array}{l}0.1206 \\
(0.014)\end{array}$ & - & - & - \\
\hline (Accounts payable/ total liabilities) $_{t-1}$ & - & - & $\begin{array}{c}0.1920^{*} \\
(0.084)\end{array}$ & - & - & - & $\begin{array}{c}0.1837^{*} \\
(0.084)\end{array}$ & - & - & - & $\begin{array}{l}0.1781^{*} \\
(0.072)\end{array}$ & - \\
\hline 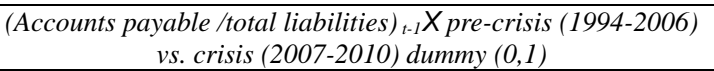 & - & - & - & - & - & - & - & - & - & - & $\begin{array}{l}0.0306 \\
(0.037)\end{array}$ & - \\
\hline Interbank interest rates & $\begin{array}{c}-0.1861^{*} \\
(0.031)\end{array}$ & $\begin{array}{c}-0.1029^{*} \\
(0.040)\end{array}$ & $\begin{array}{c}-0.1623^{*} \\
(0.071) \\
\end{array}$ & $\begin{array}{l}-0.4132 \\
(0.238) \\
\end{array}$ & $\begin{array}{c}-0.1803^{*} \\
(0.031)\end{array}$ & $\begin{array}{c}-0.1013^{*} \\
(0.035) \\
\end{array}$ & $\begin{array}{c}-0.1612^{*} \\
(0.071)\end{array}$ & $\begin{array}{l}-0.4005 \\
(0.217) \\
\end{array}$ & $\begin{array}{c}-0.1832^{*} \\
(0.033)\end{array}$ & $\begin{array}{c}-0.1031^{*} \\
(0.062)\end{array}$ & $\begin{array}{c}-0.1609^{*} \\
(0.086)\end{array}$ & $\begin{array}{l}-0.4096 \\
(0.262) \\
\end{array}$ \\
\hline Cash flow $_{t}$ capital $_{t-1}$ & $\begin{array}{c}0.2527^{*} \\
(0.106)\end{array}$ & $\begin{array}{c}0.171 \\
(0.159) \\
\end{array}$ & $\begin{array}{c}0.2628 * * \\
(0.043)\end{array}$ & $\begin{array}{l}-0.2108 \\
(0.136) \\
\end{array}$ & $\begin{array}{c}0.2560^{*} \\
(0.119)\end{array}$ & $\begin{array}{l}0.1604 \\
(0.129)\end{array}$ & $\begin{array}{c}0.2620^{* *} \\
(0.037)\end{array}$ & $\begin{array}{l}-0.2105 \\
(0.132) \\
\end{array}$ & $\begin{array}{c}0.2564 * \\
(0.110)\end{array}$ & $\begin{array}{l}0.1728 \\
(0.154)\end{array}$ & $\begin{array}{c}0.2607^{* *} \\
(0.038)\end{array}$ & $\begin{array}{l}-0.2182 \\
(0.140)\end{array}$ \\
\hline Sales growth & $\begin{array}{c}0.1397 * \\
(0.061) \\
\end{array}$ & $\begin{array}{l}0.4407 \\
(0.335) \\
\end{array}$ & $\begin{array}{c}0.1381^{*} \\
(0.065) \\
\end{array}$ & $\begin{array}{c}-0.2039^{*} \\
(0.095) \\
\end{array}$ & $\begin{array}{c}0.1441^{*} \\
(0.059) \\
\end{array}$ & $\begin{array}{l}0.4128 \\
(0.335) \\
\end{array}$ & $\begin{array}{c}0.1363^{*} \\
(0.064) \\
\end{array}$ & $\begin{array}{c}-0.2108^{*} \\
(0.091) \\
\end{array}$ & $\begin{array}{l}0.1216^{*} \\
(0.071) \\
\end{array}$ & $\begin{array}{l}0.4407 \\
(0.321) \\
\end{array}$ & $\begin{array}{c}0.1373^{*} \\
(0.071) \\
\end{array}$ & $\begin{array}{l}-0.216^{*} \\
(0.084)\end{array}$ \\
\hline Defaults in trade credit & $\begin{array}{c}-0.1795^{*} \\
(0.088)\end{array}$ & $\begin{array}{c}-0.2317^{*} \\
(0.095) \\
\end{array}$ & $\begin{array}{c}-0.1814^{*} \\
(0.093)\end{array}$ & $\begin{array}{c}-0.1361^{*} \\
(0.064)\end{array}$ & $\begin{array}{c}-0.1728^{*} \\
(0.092)\end{array}$ & $\begin{array}{c}-0.2384^{*} \\
(0.089)\end{array}$ & $\begin{array}{l}-0.182^{*} \\
(0.091)\end{array}$ & $\begin{array}{c}-0.1329 * \\
(0.068)\end{array}$ & $\begin{array}{c}-0.1827^{*} \\
(0.092)\end{array}$ & $\begin{array}{c}-0.2326^{*} \\
(0.090)\end{array}$ & $\begin{array}{c}-0.1856^{*} \\
(0.091)\end{array}$ & $\begin{array}{l}-0.143^{*} \\
(0.061)\end{array}$ \\
\hline$R^{2}($ first-stage) & 0.88 & 0.84 & 0.89 & 0.90 & 0.86 & 0.83 & 0.91 & 0.88 & 0.85 & 0.87 & 0.89 & 0.91 \\
\hline F-test for overall significance ( $p$-value) & 0.012 & 0.031 & 0.032 & 0.061 & 0.014 & 0.031 & 0.035 & 0.061 & 0.012 & 0.031 & 0.033 & 0.062 \\
\hline Hansen test ( $p$-value) & 0.116 & 0.130 & 0.111 & 0.108 & 0.115 & 0.130 & 0.112 & 0.112 & 0.119 & 0.130 & 0.115 & 0.108 \\
\hline Number of observations & 106,229 & 106,229 & 106,229 & 106,229 & 106,229 & 106,229 & 106,229 & 106,229 & 106,229 & 106,229 & 106,229 & 106,229 \\
\hline
\end{tabular}




\section{PANEL C. FULLY-CONSTRAINED FIRMS}

\begin{tabular}{|c|c|c|c|c|c|c|}
\hline & (1) & (2) & $(5)$ & (6) & (9) & (10) \\
\hline & $\begin{array}{c}\text { Capital } \\
\text { expenditure }_{t} \\
\text { / }_{\text {capital }}{ }_{t-1}\end{array}$ & $\begin{array}{l}\text { Accounts } \\
\text { payable/ } \\
\text { total } \\
\text { liabilities }\end{array}$ & $\begin{array}{c}\text { Capital } \\
\text { expenditure }_{t} \\
\text { / }_{\text {capital }}{ }_{t-1}\end{array}$ & $\begin{array}{l}\text { Accounts } \\
\text { payable/ } \\
\text { total } \\
\text { liabilities }\end{array}$ & $\begin{array}{c}\text { Capital } \\
\text { expenditure }_{t} \\
{\text { / } \text { capital }_{t-1}}^{\text {and }}\end{array}$ & $\begin{array}{c}\text { Accounts } \\
\text { payablel } \\
\text { total liabilities }\end{array}$ \\
\hline Constant & $\begin{array}{l}0.3226^{*} \\
(0.084)\end{array}$ & $\begin{array}{c}0.2817^{*} \\
(0.087)\end{array}$ & $\begin{array}{l}0.3215^{*} \\
(0.160)\end{array}$ & $\begin{array}{c}0.2934 * \\
(0.141)\end{array}$ & $\begin{array}{c}0.3264 * \\
(0.083)\end{array}$ & $\begin{array}{c}0.2951^{*} \\
(0.080)\end{array}$ \\
\hline Dependent variable $e_{t-1}$ & $\begin{array}{c}0.1471^{*} \\
(0.064)\end{array}$ & $\begin{array}{c}-0.4164^{*} \\
(0.096)\end{array}$ & $\begin{array}{c}0.1407^{*} \\
(0.063)\end{array}$ & $\begin{array}{c}-0.4105^{*} \\
(0.087)\end{array}$ & $\begin{array}{c}0.1463^{*} \\
(0.072)\end{array}$ & $\begin{array}{c}-0.4160^{*} \\
(0.093)\end{array}$ \\
\hline$\left(\text { Capital expenditure }{ }_{t} \text { capital }_{t-1}\right)_{t-1}$ & - & $\begin{array}{l}0.3043 \\
(0.327)\end{array}$ & - & $\begin{array}{l}0.3128 \\
(0.326)\end{array}$ & - & $\begin{array}{l}0.3119 \\
(0.345)\end{array}$ \\
\hline Pre-crisis (1994-2006) vs. crisis (2007-2010) dummy & - & - & $\begin{array}{l}-0.0123^{*} \\
(0.088)\end{array}$ & $\begin{array}{l}-0.0098 \\
(0.183)\end{array}$ & $\begin{array}{c}-0.0135^{*} \\
(0.069)\end{array}$ & $\begin{array}{l}0.0102^{*} \\
(0.174)\end{array}$ \\
\hline $\begin{array}{c}{\left.\text { (Capital expenditure } t_{t} / \text { capital }_{t-1}\right)_{t-1} X_{\text {pre-crisis }}(1994-2006) \text { vs. crisis }}_{(2007-2010) \text { dummy }(0,1)} \\
\end{array}$ & - & - & - & - & - & $\begin{array}{l}0.0860 \\
(0.110)\end{array}$ \\
\hline 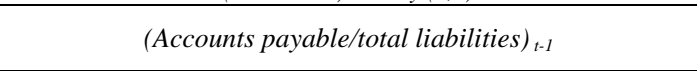 & $\begin{array}{l}0.2036^{* *} \\
(0.031)\end{array}$ & - & $\begin{array}{c}0.2392^{* *} \\
(0.031)\end{array}$ & - & $\begin{array}{c}0.2353^{* *} \\
(0.037)\end{array}$ & - \\
\hline $\begin{array}{c}\text { (Accounts payable/total liabilities) }{ }_{t-1} X_{\text {pre-crisis }}(1994-2006) \text { vs. } \\
\text { crisis }(2007-2010) \text { dummy }(0,1)\end{array}$ & - & - & - & - & $\begin{array}{l}0.1126^{*} \\
(0.054)\end{array}$ & - \\
\hline Interbank interest rates & $\begin{array}{c}-0.1203^{*} \\
(0.064)\end{array}$ & $\begin{array}{l}-0.2163 \\
(0.188)\end{array}$ & $\begin{array}{c}-0.1207^{*} \\
(0.064) \\
\end{array}$ & $\begin{array}{l}-0.2367 \\
(0.185) \\
\end{array}$ & $\begin{array}{c}-0.1201^{*} \\
(0.061) \\
\end{array}$ & $\begin{array}{l}-0.2301 \\
(0.183) \\
\end{array}$ \\
\hline Cash flow $_{t} /$ capital $_{t-1}$ & $\begin{array}{c}0.2452^{* *} \\
(0.037)\end{array}$ & $\begin{array}{l}-0.2219 \\
(0.176)\end{array}$ & $\begin{array}{c}0.2461^{* *} \\
(0.034)\end{array}$ & $\begin{array}{l}-0.2225 \\
(0.179)\end{array}$ & $\begin{array}{c}0.2463^{* *} \\
(0.035)\end{array}$ & $\begin{array}{l}-0.2156 \\
(0.170)\end{array}$ \\
\hline Sales growth & $\begin{array}{c}0.1893^{*} \\
(0.096)\end{array}$ & $\begin{array}{c}-0.0153 \\
(0.132)\end{array}$ & $\begin{array}{c}0.1951^{*} \\
(0.079)\end{array}$ & $\begin{array}{c}-0.0151 \\
(0.115)\end{array}$ & $\begin{array}{c}0.1970^{*} \\
(0.088)\end{array}$ & $\begin{array}{l}-0.0150 \\
(0.012)\end{array}$ \\
\hline Defaults in trade credit & $\begin{array}{c}-0.1804^{*} \\
(0.081)\end{array}$ & $\begin{array}{c}-0.2137^{*} \\
(0.074)\end{array}$ & $\begin{array}{c}-0.1863^{*} \\
(0.081)\end{array}$ & $\begin{array}{c}-0.2175^{*} \\
(0.076)\end{array}$ & $\begin{array}{c}-0.1816^{*} \\
(0.082)\end{array}$ & $\begin{array}{c}-0.2163^{*} \\
(0.071)\end{array}$ \\
\hline$R^{2}($ first-stage $)$ & 0.88 & 0.75 & 0.86 & 0.73 & 0.85 & 0.74 \\
\hline F-test for overall significance ( $p$-value) & 0.014 & 0.054 & 0.014 & 0.050 & 0.014 & 0.048 \\
\hline Hansen test (p-value) & 0.130 & 0.173 & 0.137 & 0.180 & 0.133 & 0.176 \\
\hline Number of observations & 15,130 & 15,130 & 15,130 & 15,130 & 15,130 & 15,130 \\
\hline
\end{tabular}

* significantly different from zero at $5 \%$ level

$* *$ significantly different from zero at $1 \%$ level 
FIGURE 1. CAPITAL EXPENDITURE AS A FRACTION OF CAPITAL: EVOLUTION OVER THE SAMPLE PERIOD
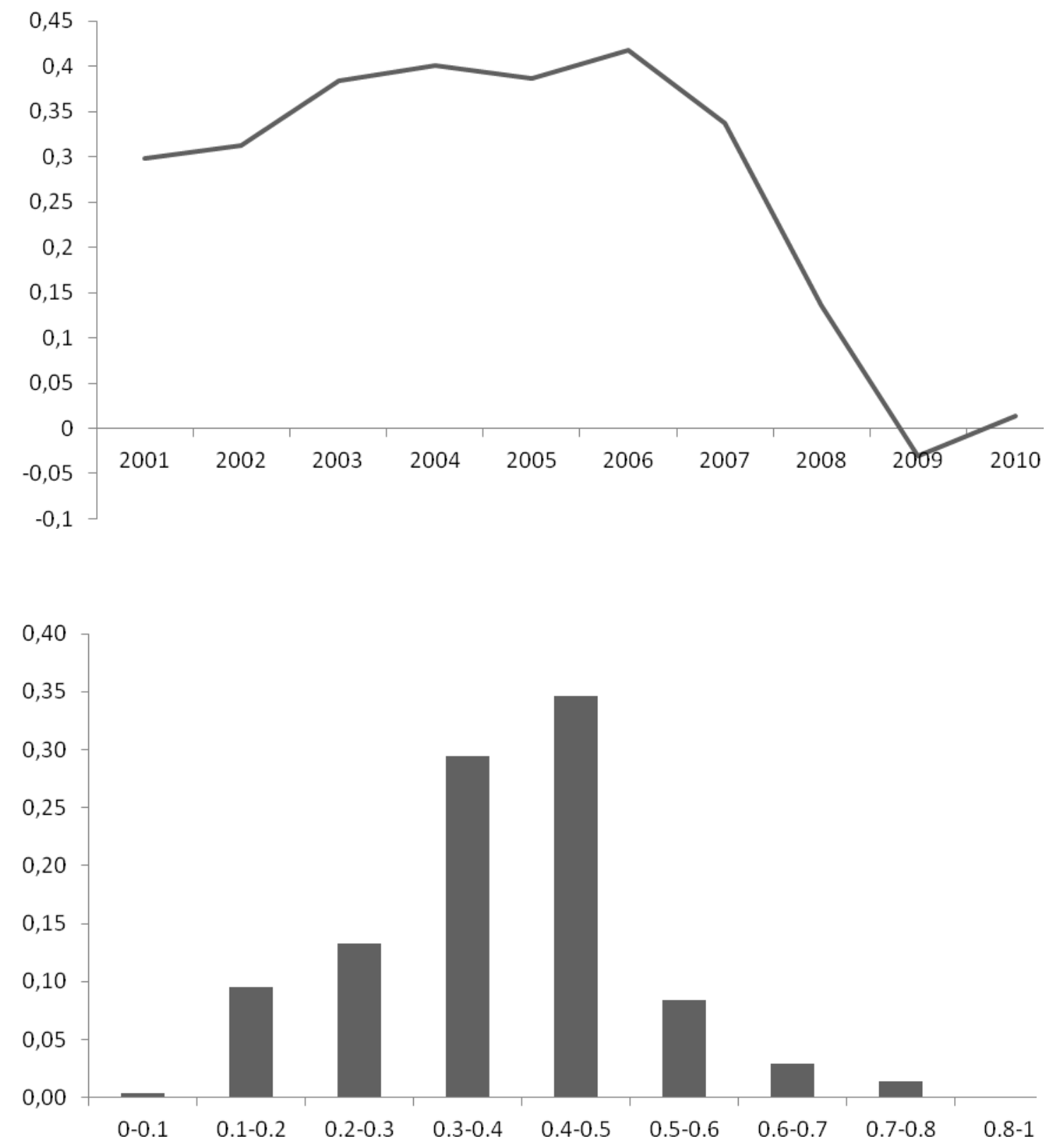


\section{APPENDIX A. DEFINTION OF THE POSITED VARIABLES}

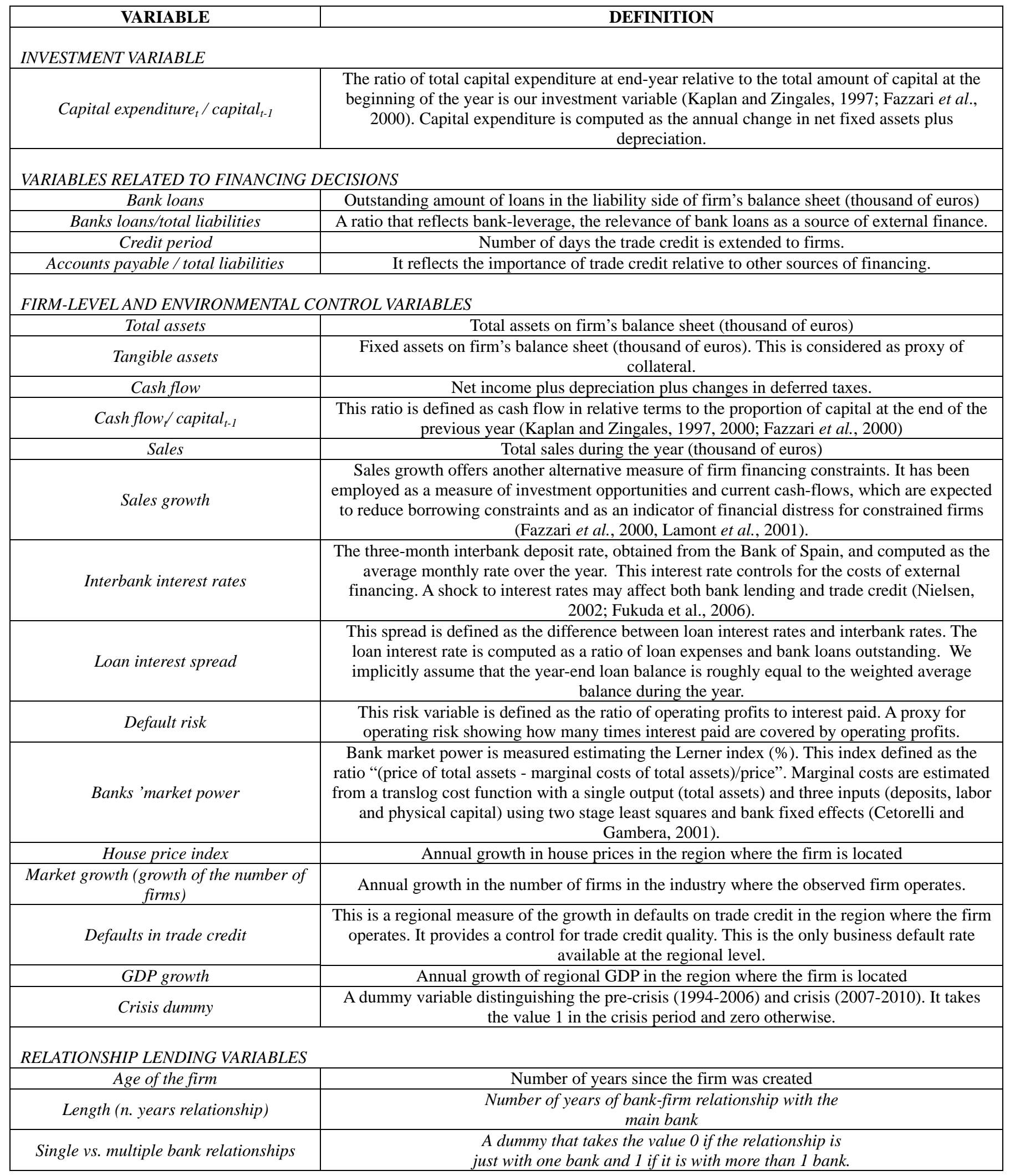




\section{APPENDIX B. SIMPLE CORRELATIONS AMONG THE VARIABLES}

\begin{tabular}{|c|c|c|c|c|c|c|c|c|c|c|c|c|c|c|c|c|c|c|c|c|c|c|}
\hline & (1) & $(2)$ & (3) & (4) & (5) & (6) & (7) & (8) & (9) & $(10)$ & (11) & $(12)$ & (13) & $(14)$ & (15) & $(16)$ & $(17)$ & (18) & (19) & $(20)$ & $(21)$ & $(22)$ \\
\hline $\begin{array}{l}\text { (1) Capital expenditure }{ }_{t} / \\
\text { capital }_{t-1}\end{array}$ & 1.00 & 0.68 & 0.61 & 0.16 & 0.43 & 0.54 & 0.37 & 0.49 & 0.38 & 0.31 & 0.38 & -0.24 & -0.32 & -0.19 & -0.18 & 0.09 & 0.20 & -0.26 & 0.48 & 0.13 & 0.36 & -0.08 \\
\hline (2) Bank loans & - & 1.00 & 0.89 & 0.30 & -0.18 & 0.26 & 0.39 & 0.53 & 0.50 & 0.61 & 0.58 & -0.17 & -0.36 & -0.14 & -0.12 & 0.06 & 0.15 & -0.13 & 0.37 & 0.44 & -0.19 & -0.39 \\
\hline (3) Banks loans/total liabilities & - & - & 1.00 & 0.26 & -0.13 & 0.23 & 0.32 & 0.46 & 0.43 & 0.58 & 0.50 & -0.13 & -0.24 & -0.09 & -0.07 & 0.03 & 0.12 & -0.08 & 0.29 & 0.32 & -0.15 & -0.31 \\
\hline (4) Credit period & - & - & - & 1.00 & -0.10 & 0.19 & 0.26 & 0.29 & 0.32 & 0.37 & 0.43 & -0.11 & -0.16 & -0.06 & -0.04 & 0.05 & 0.08 & -0.03 & 0.18 & 0.23 & -0.02 & -0.09 \\
\hline $\begin{array}{l}\text { (5) Accounts payable / total } \\
\text { liabilities }\end{array}$ & - & - & - & - & 1.00 & 0.08 & 0.28 & 0.33 & 0.36 & 0.34 & 0.48 & -0.05 & -0.09 & -0.09 & -0.10 & 0.08 & 0.13 & -0.01 & 0.13 & 0.05 & -0.06 & -0.03 \\
\hline (6) Total assets & - & - & - & - & - & 1.00 & 0.69 & 0.47 & 0.43 & 0.51 & 0.35 & 0.03 & 0.05 & $\begin{array}{l}-0.09 \\
\end{array}$ & -0.02 & 0.05 & $\begin{array}{ll}0.18 \\
\end{array}$ & -0.08 & 0.15 & 0.59 & 0.64 & 0.60 \\
\hline (7) Tangible assets & - & - & - & - & - & - & 1.00 & 0.40 & 0.36 & 0.40 & 0.28 & 0.06 & 0.03 & -0.05 & -0.06 & 0.08 & 0.16 & -0.06 & 0.19 & 0.49 & 0.53 & 0.41 \\
\hline (8) Cash flow & - & - & - & - & - & - & - & 1.00 & 0.78 & 0.72 & 0.05 & 0.08 & 0.06 & -0.13 & 0.08 & 0.07 & 0.15 & -0.05 & 0.32 & 0.31 & 0.18 & 0.15 \\
\hline (9) Cash flow $/$ capital $_{t-1}$ & - & - & - & - & - & - & - & - & 1.00 & 0.63 & 0.03 & 0.10 & 0.08 & -0.17 & 0.05 & 0.03 & 0.10 & -0.02 & 0.21 & 0.22 & 0.13 & 0.08 \\
\hline (10) Sales & - & - & - & - & - & - & - & - & - & 1.00 & 0.13 & 0.18 & 0.11 & -0.18 & -0.20 & 0.19 & 0.17 & -0.09 & 0.13 & 0.18 & 0.20 & 0.13 \\
\hline (11) Sales growth & - & - & - & - & - & - & - & - & - & - & 1.00 & 0.11 & 0.08 & -0.15 & -0.26 & 0.23 & 0.14 & -0.06 & 0.08 & 0.03 & 0.09 & 0.10 \\
\hline (12) Interbank interest rates & - & - & - & - & - & - & - & - & - & - & - & 1.00 & 0.28 & -0.19 & 0.18 & -0.19 & -0.23 & 0.26 & -0.49 & 0.02 & -0.05 & -0.03 \\
\hline (13) Loan interest spread & - & - & - & - & - & - & - & - & - & - & - & - & 1.00 & -0.13 & 0.12 & -0.28 & -0.08 & 0.10 & -0.31 & -0.04 & -0.09 & 0.18 \\
\hline (14) Default risk & - & - & - & - & - & - & - & - & - & - & - & - & - & 1.00 & 0.06 & -0.16 & -0.13 & 0.54 & -0.33 & 0.01 & -0.02 & -0.01 \\
\hline (15) Banks 'market power & - & - & - & - & - & - & - & - & - & - & - & - & - & - & 1.00 & 0.15 & -0.06 & -0.18 & 0.23 & -0.46 & 0.32 & -0.24 \\
\hline (16) House price index & - & - & - & - & - & - & - & - & - & - & - & - & - & - & - & 1.00 & 0.45 & -0.16 & 0.52 & 0.03 & -0.02 & 0.03 \\
\hline $\begin{array}{l}\text { (17) Market growth (growth of } \\
\text { the number of firms) }\end{array}$ & - & - & - & - & - & - & - & - & - & - & - & - & - & - & - & - & 1.00 & -0.08 & 0.11 & 0.05 & 0.02 & 0.08 \\
\hline (18) Defaults in trade credit & - & - & - & - & - & - & - & - & - & - & - & - & - & - & - & - & - & 1.00 & -0.41 & 0.02 & -0.06 & -0.05 \\
\hline (19) GDP growth & - & - & - & - & - & - & - & - & - & - & - & - & - & - & - & - & - & - & 1.00 & 0.04 & 0.02 & 0.01 \\
\hline (20) Age of the firm & - & - & - & - & - & - & - & - & - & - & - & - & - & - & - & - & - & - & - & 1.00 & 0.41 & 0.26 \\
\hline $\begin{array}{l}\text { (21) Length (n. years } \\
\text { relationship) }\end{array}$ & - & - & - & - & - & - & - & - & - & - & - & - & - & - & - & - & - & - & - & - & 1.00 & -0.13 \\
\hline $\begin{array}{l}\text { (22) Single vs. multiple bank } \\
\text { relationships }\end{array}$ & - & - & - & - & - & - & - & - & - & - & - & - & - & - & - & - & - & - & - & - & - & 1.00 \\
\hline
\end{tabular}

